\title{
NUMERICAL INVESTIGATIONS OF EFFECT OF INDOOR AIR QUALITY ON THERMAL COMFORT IN RESIDENTIAL BUILDINGS
}

\author{
M. KRZACZEK ${ }^{1}$, J. TEJCHMAN ${ }^{2}$
}

\begin{abstract}
The influence of the $\mathrm{CO}_{2}$ concentration in a local air zone in naturally ventilated residential houses on the residents' behaviour was numerically investigated. A numerical two-dimensional CFD model of the indoor zone based on experiments performed by the authors was used. Different resident locations in the fluid domain and different inlet velocities imposed by wind were considered in simulations. The overall thermal comfort and IAQ indices were also calculated. The investigations results show that in contrast to the overall air quality, the local $\mathrm{CO}_{2}$ was strongly dependent upon the resident location, fresh air inlet velocity and ventilation system type.
\end{abstract}

Keywords: Indoor air quality, thermal comfort, CFD, personal breathing zone, heat loads, natural ventilation, occupant behaviour

\section{INTRODUCTION}

Regardless of ventilation systems, even though the perfect air quality and thermal comfort are reached and residents confirm it in surveys [1], [2], they still open operable windows that leads to unpredicted cooling and heating loads and, consequently, to an energy consumption increase.

This residents' behaviour is very surprising and causes large discrepancy between the calculated and measured energy building performance. Residents influence the thermal comfort and indoor air quality as well as the energy performance by various factors. One main factor of the occupant behaviour is the control of the natural ventilation. Operable windows link the indoor thermal environment to ambient climate conditions, and the resulting thermal comfort and indoor air quality can be considered as a product of the ambient climate, building properties and residents behaviour.

Yun et al. [3] studied the problem of the significance of behavioural, physical and socio-economic parameters on the cooling energy in order to improve the energy

1 Gdańsk University of Technology, Faculty of Civil and Environmental Engineering, Gdańsk, Poland, e-mail: mkrzacze@pg.gda.pl

${ }^{2}$ Gdańsk University of Technology, Faculty of Civil and Environmental Engineering, Gdańsk, Poland, e-mail: tejchmk@.pg.gda.pl 
efficiency in residential buildings, but their research concerned the cooling energy only. They concluded that key building design parameters ranked low in terms of the energy performance. These parameters were related to windows, house type, age and construction standards with respect to the insulation and air tightness. This finding suggested that occupants used air conditioning as a function of exterior conditions (opposite to interior ones). The same relationship was found for the natural ventilation. Roetzel et al. [4] concluded that occupant perceived control might not only depend on the presence of windows, but also on the window opening type, window size, shape and placement, amount of persons controlling windows, window accessibility or hierarchical relation to colleagues in the case of a shared control over windows. A direct contact between residents and ambient climate is usually limited to the solar radiation and for the natural ventilation to the outdoor air flowing into the indoor zone through inlet gaps. The solar radiation and outdoor air significantly influence indoor climate parameters. The solar radiation affects more the thermal comfort than the air quality, while the fresh outdoor air modifies the thermal comfort and indoor air quality. The window opening is registered even during cloudy days [2]. Thus, it is reasonable to investigate the behaviour of residents with respect to the fresh air inlet parameters and its flow pattern in the indoor zone to explain the unpredicted residents' behaviour.

The indoor air quality (IAQ), as the air nature in the indoor environment related to the occupant health and comfort is not an easily defined concept. The term comfort is not commonly used with respect to the indoor air quality and it is mainly linked with the lack of discomfort due to the odour and sensory irritation. In a broad context, it is the result of complex interactions between building, building systems and people. Investigations of all types of indoor air pollutants for the general air quality monitoring and assessment are complex. In many studies it was suggested that the measurement and analysis of the indoor carbon dioxide $\left(\mathrm{CO}_{2}\right)$ concentration could be useful for understanding IAQ and ventilation effectiveness [5], [6]. The indoor carbon dioxide is relatively easy to be measured and its low level in the indoor air usually corresponds to a low level of volatile organic compounds (VOCs) and indoor airborne pollutants. According to the standard definition [7], the $\mathrm{CO}_{2}$ concentration is related to the indoor zone sub-space called the Breathing Zone (BZ), which is relatively large and close to the indoor zone volume. A conventional ventilation system should be designed in a way to create a uniform environment in the entire BZ. However, there are two obvious problems: the fresh air is mixed with indoor air pollutants prior to its inhalation by occupants and individual thermal preferences are not taken into account. Fanger [8] proposed a ventilation supply method, called the personalized air (PA) system, based on observations of dominating fluid patterns in indoor zones. In this method, the fresh air is supplied directly to the breathing zone with a small fluid velocity. As result, residents inhale air in the unpolluted core of the supplied jet. The method assumes implicitly that there exists a local poor air zone which is located near the resident head [9], [10]. The local zone is created by the air- $\mathrm{CO}_{2}$ mixture exhausted by residents [9]. Moreover, 
residents inhale the air supplied from the same local zone. The existence of a local poor air zone, called in our study the Personal Breathing Zone (PBZ), can result in the unpredicted resident dissatisfaction, even though, the air quality in BZ is within the comfort range. Dissatisfied residents want to recover the comfort (satisfaction) by e.g. opening windows [10].

In the paper, the influence of the $\mathrm{CO}_{2}$ concentration in the Personal Breathing Zone in naturally ventilated low-energy buildings on the residents' behaviour was numerically investigated using first a simplified 2D model. The numerical model of the indoor zone was based on experiments performed by the authors in the colony of 22 identical low-energy residential houses equipped with different ventilation systems located in Germany by Leipzig [1], [2]. The experimental results showed for all test houses that the air quality was good and the thermal conditions were within the comfort range. These conclusions were confirmed by residents in surveys. However, a constant monitoring of test houses showed that the residents opened operable windows what led to unpredicted heat losses. Our numerical investigations using the CFD model were limited to two reference residential houses equipped with the natural ventilation system with and without single exhaust ventilators and a radiator space heating system. One location of the fresh air inlet was considered, namely above the window. The air- $\mathrm{CO}_{2}$ mixture flow conditions in the indoor zone corresponded to experimental measurements. In order to investigate the $\mathrm{CO}_{2}$ concentration in the zones $\mathrm{BZ}$ and PBZ, different resident locations and inlet velocities imposed by wind were numerically tested. The overall thermal comfort indices were taken into account as well as the IAQ indices.

\section{Model of Ventilated ZONE}

To numerically investigate the fluid flow pattern and to track the $\mathrm{CO}_{2}$ concentration in the indoor air and breathing zones (standard and personal), the house was considered as one indoor zone which represented the dining and living room. A simplified twodimensional model was assumed (Figure 1). The indoor zone was modelled together with an exhaust duct and created one fluid flow domain. The exhaust duct was added to the model to make it more realistic, especially in the case of the natural ventilation without fans, driven by the air- $\mathrm{CO}_{2}$ mixture temperature differences. The inlet gap configuration above window was considered (Figure 1). It was assumed that the indoor air was warmed up by a radiator space heating system. The natural ventilation could be enforced by a single fan located in the outlet gap (the exhaust duct inlet). In the ventilated zone, the fluid velocity could reach $1.6 \mathrm{~m} / \mathrm{s}$. It corresponded with the Reynolds number of 21000. Thus, turbulent flow of the compressible Newtonian fluid was considered under a two-dimensional steady state. The physical problem was defined by the law of the conservation of mass, momentum and energy for the air- $\mathrm{CO}_{2}$ mixture. From the mass conservation law, the continuity equation was derived: 


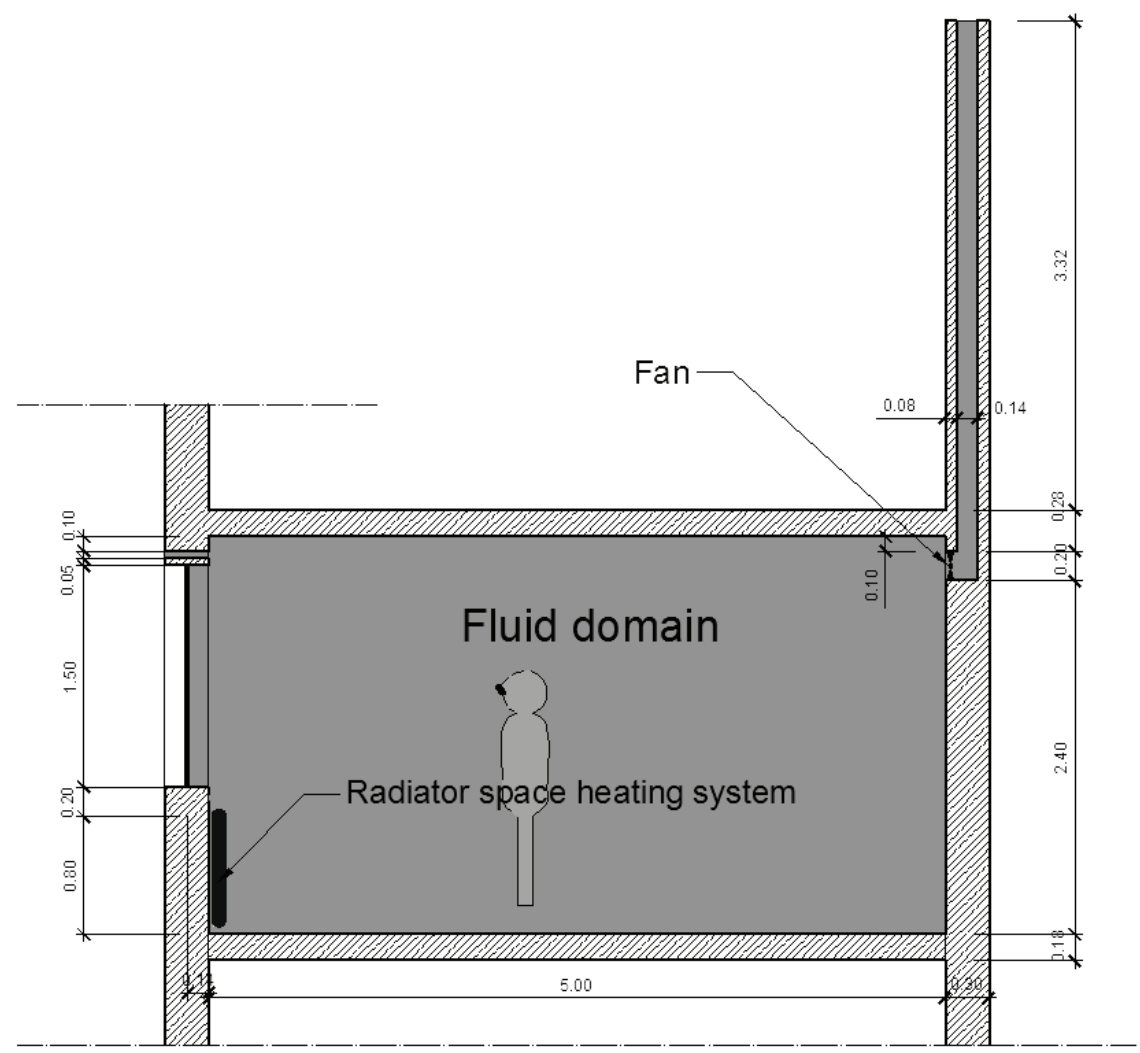

Fig. 1. The 2D model of ventilated zone and fluid domain

$$
\frac{\partial p}{\partial t}+\nabla \cdot(\rho \boldsymbol{U})=0
$$

where $\boldsymbol{U}$ is vector of velocity $\boldsymbol{U}_{x, y}, \rho$ is the density $\left(\mathrm{kg} / \mathrm{m}^{3}\right)$ and $t$ is the time. For the Newtonian fluid, the momentum equation was as follows:

$$
\frac{\partial(\rho \boldsymbol{U})}{\partial t}+\nabla \cdot(\rho \boldsymbol{U} \otimes \boldsymbol{U})=-\nabla p+\nabla \cdot \tau+\boldsymbol{S}_{M},
$$

where the stress tensor, $\tau$, is related to the strain rate by

$$
\tau=\mu\left(\nabla \boldsymbol{U}+\left(\nabla \boldsymbol{U}^{T}\right)-\frac{2}{3} \delta \nabla \cdot \boldsymbol{U}\right),
$$

and $\mu$ is dynamic viscosity, $\delta$ is Kronecker Delta function. 
The governing energy equation for low-speed flows was

$$
\frac{\partial(\rho h)}{\partial t}+\nabla \cdot(\rho \boldsymbol{U} h)=\nabla \cdot(\lambda \nabla T)+\tau: \nabla \boldsymbol{U}+\boldsymbol{S}_{E}
$$

where $h$ is actually interpreted as internal energy $\left[\mathrm{m}^{2} / \mathrm{s}^{2}\right]$ and $\boldsymbol{S}_{E}$ is energy source. In our study, the standard $k-\varepsilon$ turbulence model was applied [11]. The turbulence model was modified to model buoyancy [12], however, it was still only a fit for fully developed turbulent flow. Two different gases (air and $\mathrm{CO}_{2}$ ) were tracked. A single momentum equation (Eqs. 2.2 and 2.3) was solved for the flow field. The properties for this equation were calculated from species fluids and their mass fractions for density, viscosity and conductivity. The governing equation for the air transport was:

$$
\frac{\partial\left(\rho Y_{\text {air }}\right)}{\partial t}+\nabla \cdot\left(\rho Y_{\text {air }} v\right)-\nabla \cdot\left(\rho D_{\text {mair }} \nabla Y_{\text {air }}\right)=0
$$

where $Y_{\text {air }}$ is the mass fraction for the air, $v$ is the velocity vector $[\mathrm{m} / \mathrm{s}]$ and $D_{m \text { air }}$ denotes the mass diffusion coefficient $\left[\mathrm{m}^{2} / \mathrm{s}\right]$. The equation for $\mathrm{CO}_{2}$ was not solved directly. The mass fraction for $\mathrm{CO}_{2}$ was calculated at each node from the identity condition:

$$
Y_{\mathrm{CO} 2}=1-Y_{\text {air }}
$$

At each node, the fluid density was computed as a function of mass fractions and molecular weights of gases (air and $\mathrm{CO}_{2}$ ):

$$
\rho=\frac{P}{R T \sum_{1}^{2} \frac{Y_{i}}{M_{i}}},
$$

with $R$ as the universal gas constant, $M_{i}$ the molecular weight of the ith species, $P$ the pressure degree of freedom and $T$ the absolute temperature $[\mathrm{K}]$. The opaque of the fluid domain was in a contact with a solid body of external and internal walls of the indoor zone and exhaust duct. The boundary conditions for velocity components at the mixture inlet gap were:

$$
\begin{aligned}
& v_{x}=v_{\text {inlet }}, \\
& v_{y}=0 .
\end{aligned}
$$

The boundary conditions for velocity components at the mixture outlet in the exhaust duct were:

$$
\frac{\partial v}{\partial n}=0 .
$$


The boundary conditions for the temperature were: at the mixture inlet gap:

$$
T=T_{\text {inlet }},
$$

and at the mixture outlet in the exhaust duct:

$$
\frac{\partial T}{\partial n}=0 .
$$

The mixture velocity inlet profile was applied following the power-law equation [9]:

$$
v_{\text {inlet }}=v_{\text {ref }}\left(\frac{z}{h}\right)^{a},
$$

where $v_{\text {inlet }}$ is the wind speed at the arbitrary height $z$ above the ground level, $h$ is the weather station sensor height, $5 \mathrm{~m}$, where the reference prevailing velocity $v_{\text {ref }}$ was recorded in the climate database during experiments, and $a$ - the exponential coefficient, taken as 0.2 [9] (the value corresponds to a rough-rural terrain). The wind speed was equal to $3.0 \mathrm{~m} / \mathrm{s}$ with the south-west west $(\mathrm{SW}-\mathrm{W})$ wind direction. The reference wind speed $v_{\text {ref }}$ for the wall faced south was $1.13 \mathrm{~m} / \mathrm{s}$ and consequently $v_{\text {inlet }}=0.98 \mathrm{~m} / \mathrm{s}$ (Eq. 2.7). The solar radiation reflecting the external wall surface was modelled by the equivalent convection heat flux. The equivalent value increased the convection heat exchange rate on the surface of the external wall up to a sum of the convection and radiation rate. The convection and radiation heat flux was characterized by the sol-air temperature $T_{e-\text {-sol }}$ defined as [10], [13]:

$$
T_{e-s o l}=T_{o}+\frac{a I}{h_{e}},
$$

where $T_{o}$ - the outdoor air temperature $\left[{ }^{\circ} \mathrm{C}\right], a$ - the solar absorptivity of the wall outdoor surface $[-]$ and $I-$ the incident total solar radiation $\left[\mathrm{W} / \mathrm{m}^{2}\right]$. It was assumed that the absorptivity coefficient, 0.65 , was equivalent to the grey painting. Besides the sol-air temperature, the wind driven changes of the convective heat coefficient $h_{e}$ influenced the heat exchange rate on the external wall surface. Thus the convective heat coefficient was defined by the empirical formula [14]:

$$
h_{e}(t)=\max \left[5, \frac{8.6 v(t)^{0.6}}{l^{0.4}}\right],
$$

where $v(t)$ is the wind speed $[\mathrm{m} / \mathrm{s}]$ and $l$ is the cubical root of the building volume $[\mathrm{m}]$. The inlet temperature $T_{\text {inlet }}$ was $5.3^{\circ} \mathrm{C}$. For the natural ventilation with the exhaust fan, the fan was modelled as an artificially imposed momentum source that provided momentum source terms. The pressure rise associated with the fan model was given by 
the pressure gradient times the flow length through elements. The pressure was treated as a quadratic function of velocity:

$$
\frac{\partial p}{\partial x_{\text {fan }}}=C_{1}+C_{2}\left|v_{x}\right|+C_{3} v_{x}^{2}
$$

where $C_{1}, C_{2}$ and $C_{3}$ are the coefficients determined for the exhaust ventilator V2A (max. performance $80 \mathrm{~m}^{3} / \mathrm{h}$ ) [14]. The boundary conditions for the velocity components on the surfaces in a contact with internal walls, floor, ceiling and the exhaust duct were:

$$
\begin{aligned}
& v_{x}=0 \\
& v_{y}=0
\end{aligned}
$$

On the fluid domain boundary with the external wall and window, the heat flux was assumed to be (Figure 2):

$$
q=h_{e ~ e q v}\left(T_{F i}-T_{e}\right)
$$

where $T_{F i}$ is the temperature of the internal surface of the wall or window $\left[{ }^{\circ} \mathrm{C}\right], T_{e}$ is the ambient air temperature $\left[{ }^{\circ} \mathrm{C}\right]$ and $h_{e}$ eqv is the equivalent convective heat transfer coefficient $[\mathrm{W} /(\mathrm{m} \mathrm{K})]$. The convection heat flux $q$ was characterized by the equivalent convective heat transfer coefficient $h_{\text {e eqv }}$. For steady-state heat transfer problems, the equivalent convective heat transfer coefficient $h_{e \text { eqv }}$ was independent of ambient and
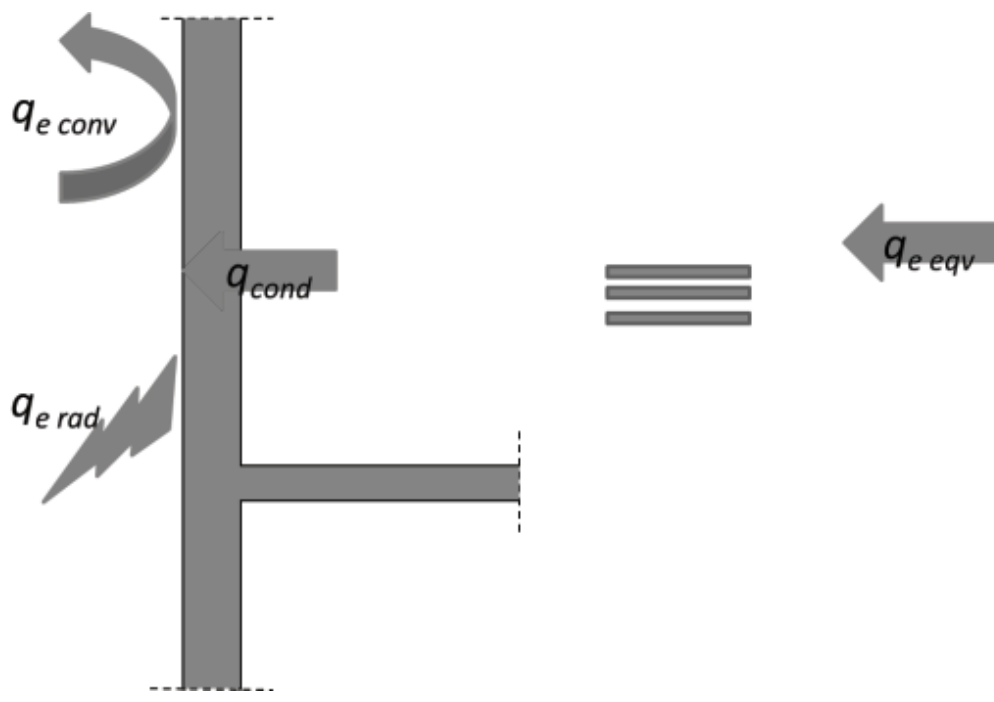

Fig. 2. The equivalent convection heat flux at boundary with external wall and window 
indoor climate conditions. The conduction heat flux $q_{\text {cond }}$ in a steady-state heat transfer for the external wall and window was:

$$
q_{\text {cond }}=U\left(T_{i}-T_{e}\right) \text {, }
$$

and the equivalent convection heat flux $q_{e}$ eqv was:

$$
q_{\text {e eqv }}=h_{\text {e eqv }}\left(T_{F i}-T_{e}\right) \text {, }
$$

where $U$ is the coefficient of the heat transmission $\left[\mathrm{W} /\left(\mathrm{m}^{2} \mathrm{~K}\right)\right], T_{e}$ is the ambient air temperature $\left[{ }^{\circ} \mathrm{C}\right]$ and $T_{i}$ is the indoor air- $\mathrm{CO}_{2}$ mixture temperature $\left[{ }^{\circ} \mathrm{C}\right]$. The equivalent convective heat transfer coefficient $h_{e \text { eqv }}$ was according to the assumption $q_{\text {cond }}$ equalled to $q_{\text {e eqv }}$ :

$$
h_{e ~ e q v}=\frac{U\left(T_{i}-T_{e}\right)}{\left(T_{i}-U\left(T_{i}-T_{e}\right) \frac{1}{h_{i}}-T_{e}\right)},
$$

where $h_{i}$ denotes the convective heat transfer coefficient [12] on the internal surface of the external wall or window. For the above assumptions, the equivalent convective heat transfer coefficient $h_{\text {e eqv }}$ was $0.222 \mathrm{~W} /\left(\mathrm{m}^{2} \mathrm{~K}\right)$ and $1.370 \mathrm{~W} /\left(\mathrm{m}^{2} \mathrm{~K}\right)$, for the external wall and window, respectively. Opposite to surfaces in a contact with external walls and windows, other surfaces of the fluid domain were considered to be adiabatic. The radiator heating system is simulated by a constant heat flux, which was generated by the radiator surface. It is assumed that in the indoor zone one double-panel radiator of $0.7 \mathrm{~m}$ high and $1.0 \mathrm{~m}$ width was installed. The radiator performance was investigated by Beck et al. [15], [16]. They found that depending on the panel structure and fluid supply temperature, the radiator panel $(0.6 \mathrm{~m} \times 0.6 \mathrm{~m})$ could release heat up to $1800 \mathrm{~W}$. However, the radiation heat transfer into the room from the radiator facing was more than $25 \%$ and could reach up to $50 \%$. It was concluded that the heat flux and surface temperature varied over the radiator surface. To simplify the radiator heat exchange model, it was more realistic to define a constant temperature of the radiator surface $\left(55^{\circ} \mathrm{C}\right)$ rather than a constant value of the heat flux. To simplify a flow analysis in the indoor zone, it was assumed that the only heat source in the indoor zone was a resident. The heat source was distributed over his body surface. Figure 10 presents the locations of the heat source in the fluid domain. Murakami el at. [17] studied the airflow, thermal radiation and moisture transport for predicting a heat release from human bodies. They reported that the heat release from a human body in a standing position to the surrounding environment was $29.14 \mathrm{~W} / \mathrm{m}^{2}$ by convection and the mean convective heat transfer coefficient was $4.95 \mathrm{~W} / \mathrm{m}^{2} \mathrm{~K}$. Following the above conclusions and considering the skin surface area of $1.5696 \mathrm{~m}^{2}$ [17], the constant heat flux of $11.55 \mathrm{~W} / \mathrm{m}^{2}$ along the resident body surface was taken. 


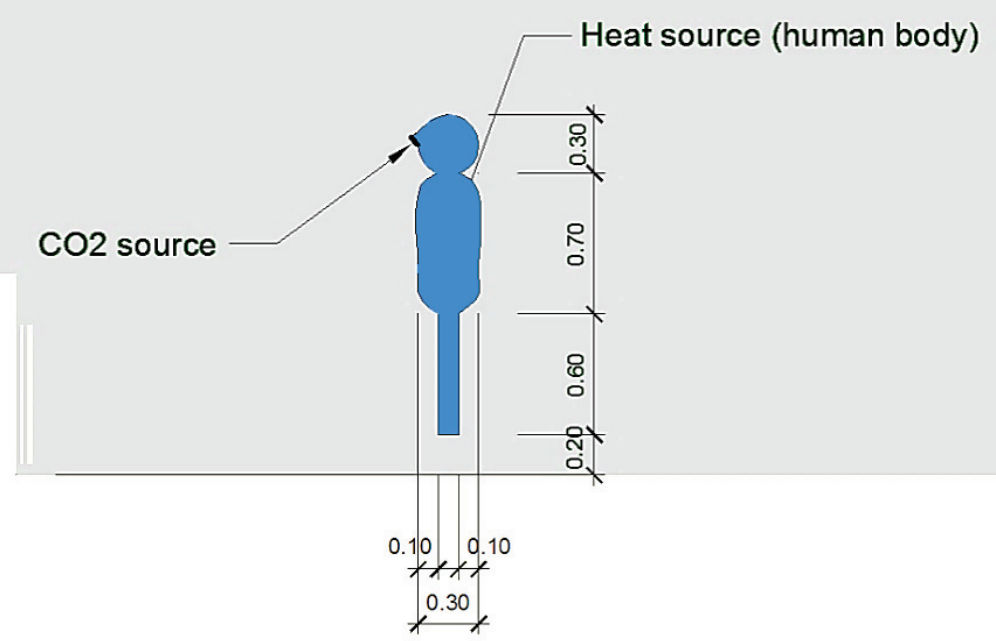

Fig. 3. Definition of heat source and $\mathrm{CO}_{2}$ source in fluid domain

In a composite gas analysis, the species concentration depended strongly on boundary and initial conditions. The boundary conditions were defined by the $\mathrm{CO}_{2}$ concentration over the fluid domain boundaries and the initial conditions are defined by the initial $\mathrm{CO}_{2}$ distribution over the fluid domain. Following $\mathrm{Li}$ et al. [18], the ambient $\mathrm{CO}_{2}$ concentration was approximately $700 \mathrm{mg} / \mathrm{m}^{3}$ (389 ppm). Consequently, the $\mathrm{CO}_{2}$ concentration at the inlet gap was $C_{i n l}=389 \mathrm{ppm}$. The initial (nominal) $\mathrm{CO}_{2}$ distribution in the fluid domain was assumed (according to experimental results [2] to be uniform and equal to $1266.6 \mathrm{ppm}$ without ventilators and $646.7 \mathrm{ppm}$ with ventilators. For any other boundaries of the fluid domain:

$$
\frac{\partial C}{\partial n}=0
$$

In the indoor zone model, the main $\mathrm{CO}_{2}$ sources were residents. To track the $\mathrm{CO}_{2}$ concentration, one resident occupying the indoor zone was assumed. The respiration process of human beings was simulated by several researchers [19], [20] who concluded that the frequency of respiration under light physical work was 17 times per minute with the time-mean rate of $8.4 \mathrm{l} / \mathrm{min}$. Following their conclusions, a steady exhalation process was chosen (a resident exhaled $\mathrm{CO}_{2}$ into the indoor zone with the rate $\dot{S}=0.14 \times 10^{-3} \mathrm{~m}^{3} / \mathrm{s}$ ). According to Yanes et al. [21], the average $\mathrm{CO}_{2}$ concentration in the exhaled air by human beings was $55,100 \mathrm{ppm}$. Hence, the $\mathrm{CO}_{2}$ source was modelled 
as the source generating the air- $\mathrm{CO}_{2}$ mixture of $55,100 \mathrm{ppm}$ (per person) $\mathrm{CO}_{2}$ concentration with the velocity $v_{x}=v_{x e x h}$ and $v_{y}=v_{y e x h} \mathrm{~m} / \mathrm{s}$.

The ANSYS software package [22] was used to solve Eqs. 2.1-2.4. In numerical simulations, the fluid domain configuration with the inlet gap located above the window was taken into account. Four resident locations with regards to the external wall (Figure 4) were tested. To study the influence of a variable resident location and respective flow patterns on the overall IAQ indices, the average breathing zone BZ was simulated in a different way than the one proposed in the guideline [11] (Figure 4). The breathing zone started at $1 \mathrm{~m}$ from the floor and from all walls and ends at the ceiling. This location corresponded to the measurement equipment location [8] and enabled us a comparison with experimental results. Following the inhalation model by Murakami et al. [23], the Personal Breathing Zone PBZ was assumed to be a rectangular region located in front of the resident face (Figure 6). The fluid domain was simulated as a multi-area region and a variable mesh density was applied.

The numerical results were compared with the experimental ones [24]. The experimental tests were carried out in 22 identical residential houses standing in one row, located in Germany by Leipzig [2].The residential area of the medium-size house was $114 \mathrm{~m}^{2}$, where the area of $102 \mathrm{~m}^{2}$ was the heating area. Each house had two external walls exposed to the ambient air. The residential rooms with large window areas were oriented towards the south. For numerical investigations, 2 residential houses tested were considered:

1) one equipped with natural gravitational ventilation (house ' 1 ') and

2) second equipped with natural ventilation enforced by single exhaust ventilators (house '2').

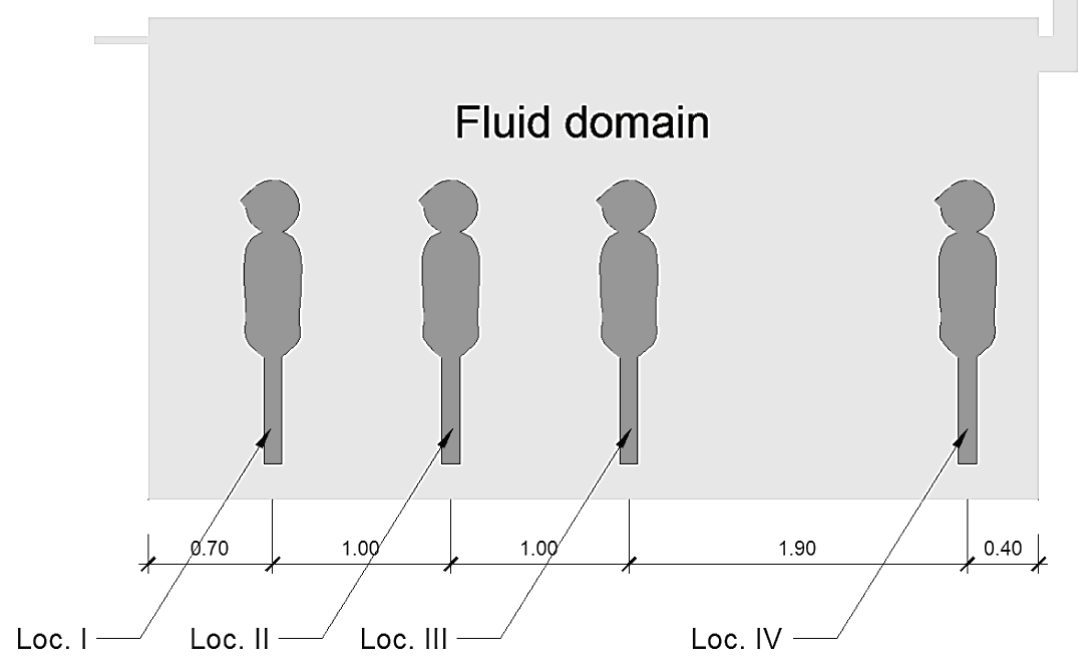

Fig. 4. Locations of resident in indoor zone (fluid domain) 


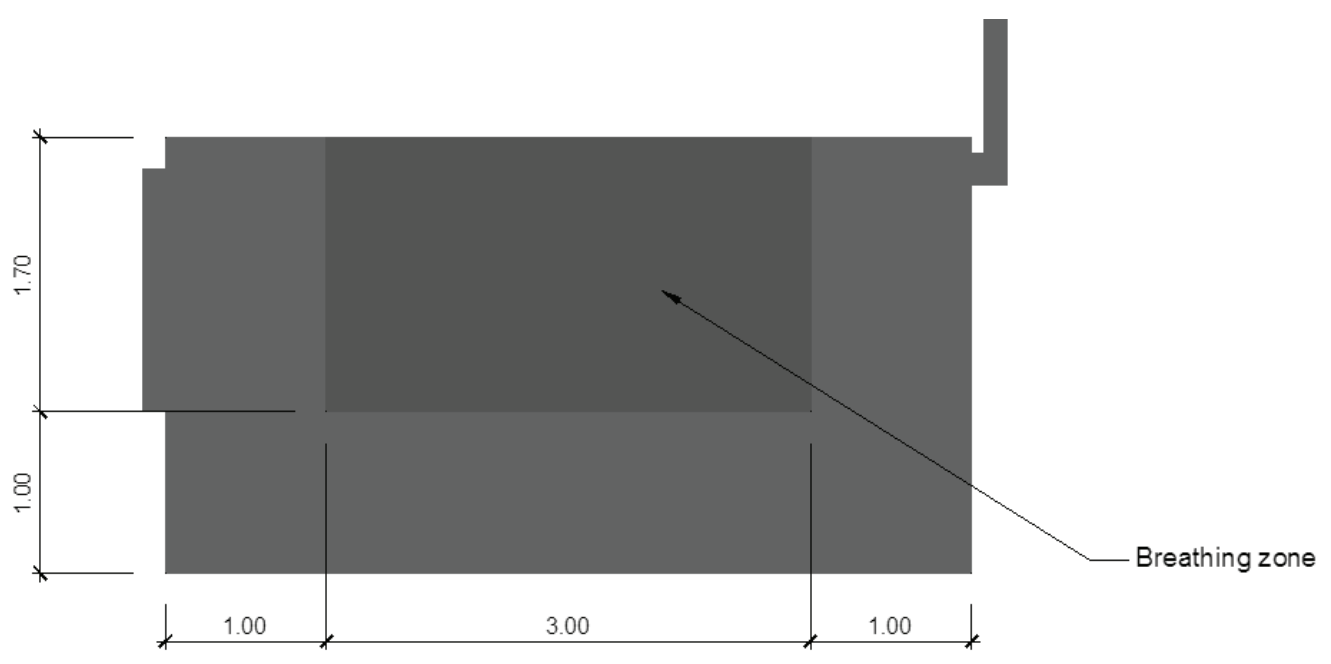

Fig. 5. The breathing zone location in fluid domain

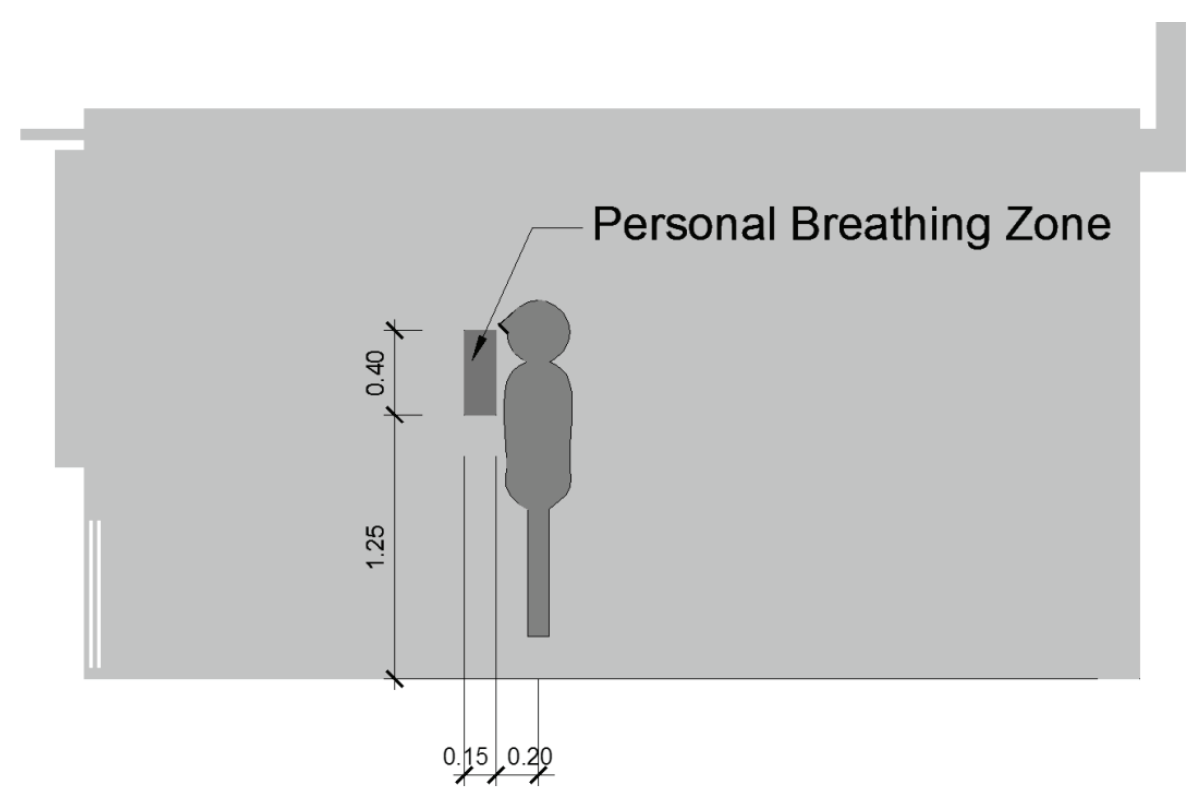

Fig. 6. The Personal Breathing Zone location in fluid domain

In the case of the natural ventilation with exhaust ventilators, the area of the air supply included children rooms, living rooms and bedrooms. However, a bathroom, toilet and rooms with the internal building installation were associated to the area of the 
air outlet. The single air ventilators were used, and each of them operated separately. The output of the stream in the mode of the basic ventilation was around $0.32 \mathrm{Wh} / \mathrm{m}^{3}$ (the value of $0.25 \mathrm{Wh} / \mathrm{m}^{3}$ for the ventilation output friendly for users was unfortunately exceeded). The following parameters were monitored in houses by sensors: air humidity, air quality (expressed by the concentration of both $\mathrm{CO}_{2}$ and malodours), temperature, electricity consumption, gas consumption, heat consumption, working time of the window ventilation (windows totally and slightly open), working time of the ventilators and number of residents [8]. In addition, sun radiation, wind power, wind direction, air humidity, air quality and the air temperature were registered outside houses. The time interval between consecutive measurements was 1 hour.

\section{THERMAL COMFORT AND IAQ INDICES}

For evaluation of results, the comfort indices PMV, PPD and PD were used. The calculation procedure was performed by means of a special post-processing algorithm, which predicted the indices in each node and element of the FE mesh. The PMV was computed according to the algorithm [25]:

$$
\operatorname{PMV}_{i}=\left[0.303 e^{(-0.036 M)}+0.028\right] T L,
$$

where $M$ denotes the initial standard value of the prescribed activity level and $T L$ stands for the thermal load on the body. For PMV, the metabolic rate for a standing position and light activity was considered. The local PMVs were averaged within the area of the occupied zone as follows:

$$
\mathrm{PMV}_{\mathrm{avg}}=\frac{\sum_{k=1}^{n} \mathrm{PMV}_{k} \cdot A_{k}}{\sum_{k=1}^{n} A_{k}}
$$

where $\mathrm{PMV}_{k}$ is averaged over the $k$-th element, $A_{k}$ is the area of the $k$-th element and $n$ is the number of finite elements. The PMV predicts the mean value of thermal votes of a large group of people exposed to the same environment. But individual votes are scattered around this mean value and it is useful to predict the number of people likely to feel uncomfortably warm or cool. The PPD is the index that establishes a quantitative prediction of the percentage of thermally dissatisfied people who feel too cool or too warm [25]:

$$
P P D=100-95 \cdot \exp \left(-0.03353 \cdot P M V_{a v g}^{4}-0.2179 \cdot P M V_{a v g}^{2}\right) .
$$

If the floor is too warm or too cool, the occupants feel uncomfortable owing to thermal sensation of their feet. The percentage dissatisfied PD as a function of the floor temperature [\%] was computed as follows [25]: 


$$
P D=100-94 \cdot \exp \left(-1.387+0.118 \cdot T_{f}-0.0025 \cdot T_{f}^{2}\right)
$$

where $T_{f}$ is the average floor temperature in $\left[{ }^{\circ} \mathrm{C}\right]$. The overall ventilation effectiveness for the temperature distribution $\bar{\varepsilon}_{t}$ provides a quantitative index related to the way in which the heat is distributed inside the indoor zone. The higher value of $\bar{\varepsilon}_{t}$, the more is the homogeneous temperature distribution. Following the expression by Awbi [26], the overall ventilation effectiveness for the temperature distribution $\bar{\varepsilon}_{t}$ was defined as

$$
\overline{\varepsilon_{t}}=\frac{T_{\text {outlet }}-T_{\text {inlet }}}{T_{\text {average }}-T_{\text {inlet }}},
$$

where $T_{\text {outlet }}$ is the average temperature for the air- $\mathrm{CO}_{2}$ mixture at the outlet, $T_{\text {average }}$ denotes the average temperature for the air- $\mathrm{CO}_{2}$ mixture all over the breathing zone and $T_{\text {inlet }}$ is the average temperature for the air- $\mathrm{CO}_{2}$ mixture at the inlet. The temperatures $T_{\text {average, }}, T_{\text {outlet }}$ and $T_{\text {inlet }}$ were computed by the following equations:

$$
T_{\text {average }}=\frac{\int_{A_{Z}} T d A}{A_{Z}}
$$

$$
T_{\text {outlet }}=\frac{\int_{S_{r} T d S}}{S_{r}}
$$

$$
T_{\text {inlet }}=\frac{\int_{S_{S}} T d S}{S_{S}},
$$

where $A_{z}$ denotes the area of the breathing zone, $T$ is temperature in point of $(x, y), S_{r}$ is the outlet surface and $S_{s}$ is the inlet surface.

The indoor air quality was investigated in terms of the ventilation effectiveness, based on the $\mathrm{CO}_{2}$ concentration in the Breathing Zone (Figure 4). The ventilation effectiveness $\eta_{V}$ [25] was a measure of how the supply airflow mixes with the breathing zone for a removal of $\mathrm{CO}_{2}$ or other pollutants:

$$
\eta_{V}=\frac{C_{r}-C_{s}}{C_{z}-C_{s}}
$$

where $C_{r}$ - average $\mathrm{CO}_{2}$ return concentration [ppm], $C_{s}$ - average $\mathrm{CO}_{2}$ supply concentration [ppm], $C_{z}$-average $\mathrm{CO}_{2}$ concentration in the breathing zone [ppm]. The average $\mathrm{CO}_{2}$ concentrations $C_{r}, C_{s}$ and $C_{z}$ were computed from:

$$
C_{z}=\frac{\int_{A_{z}} C d A}{A_{z}},
$$




$$
\begin{gathered}
C_{r}=\frac{\int_{S_{r}} C d S}{S_{r}}, \\
C_{S}=\frac{\int_{S_{S}} C d S}{S_{S}},
\end{gathered}
$$

where $C$ is the $\mathrm{CO}_{2}$ concentration at the point $(x, y)$.

\section{Numerical Results}

The simulation results were divided into two main groups (Table 1), called:

- house 1: residential house equipped with natural gravitational ventilation (cases $1-24)$,

- house 2: residential house equipped with natural ventilation with exhaust ventilators (cases 25-48).

Next, the main 2 groups (houses) are divided into the groups which differ in the resident location:

- groups (a) and (e): location I,

- groups (b) and (f): location II,

- groups (c) and (g): location III,

- groups (d) and (h): location IV.

Each group was divided into the subgroups (i)-(vi) related to the different inlet air velocity: $0.05 \mathrm{~m} / \mathrm{s}, 0.20 \mathrm{~m} / \mathrm{s}, 0.40 \mathrm{~m} / \mathrm{s}, 0.60 \mathrm{~m} / \mathrm{s}, 0.80 \mathrm{~m} / \mathrm{s}$ and $0.98 \mathrm{~m} / \mathrm{s}$ (meeting the prevailing climate conditions).

The health and toxicity implications of $\mathrm{CO}_{2}$ on the human health were reviewed by Hodgson et al. [27]. His investigations indicated that there was no evidence that $\mathrm{CO}_{2}$ influenced the normal functions of human beings if the concentration of $\mathrm{CO}_{2}$ remained lower than $8500 \mathrm{ppm}$. Hence, all following figures presenting the investigations results of the $\mathrm{CO}_{2}$ concentration were limited up to $8500 \mathrm{ppm}$. For normal living conditions, the measured values of $\mathrm{CO}_{2}$ above $1000 \mathrm{ppm}$ resulted in the people dissatisfaction. However, in naturally ventilated zones occupants were some less sensitive to the $\mathrm{CO}_{2}$ concentration level. Thus, according to [28], [29], the air quality dissatisfaction limit was assumed to be $1389 \mathrm{ppm}$ (1000 ppm over the ambient $\mathrm{CO}_{2}$ concentration) during natural ventilation with and without exhaust ventilators. Like the $\mathrm{CO}_{2}$ concentration, Figures presenting PMV index were limited to the seven point-scale [25]. 
Table 1

Description of simulation cases

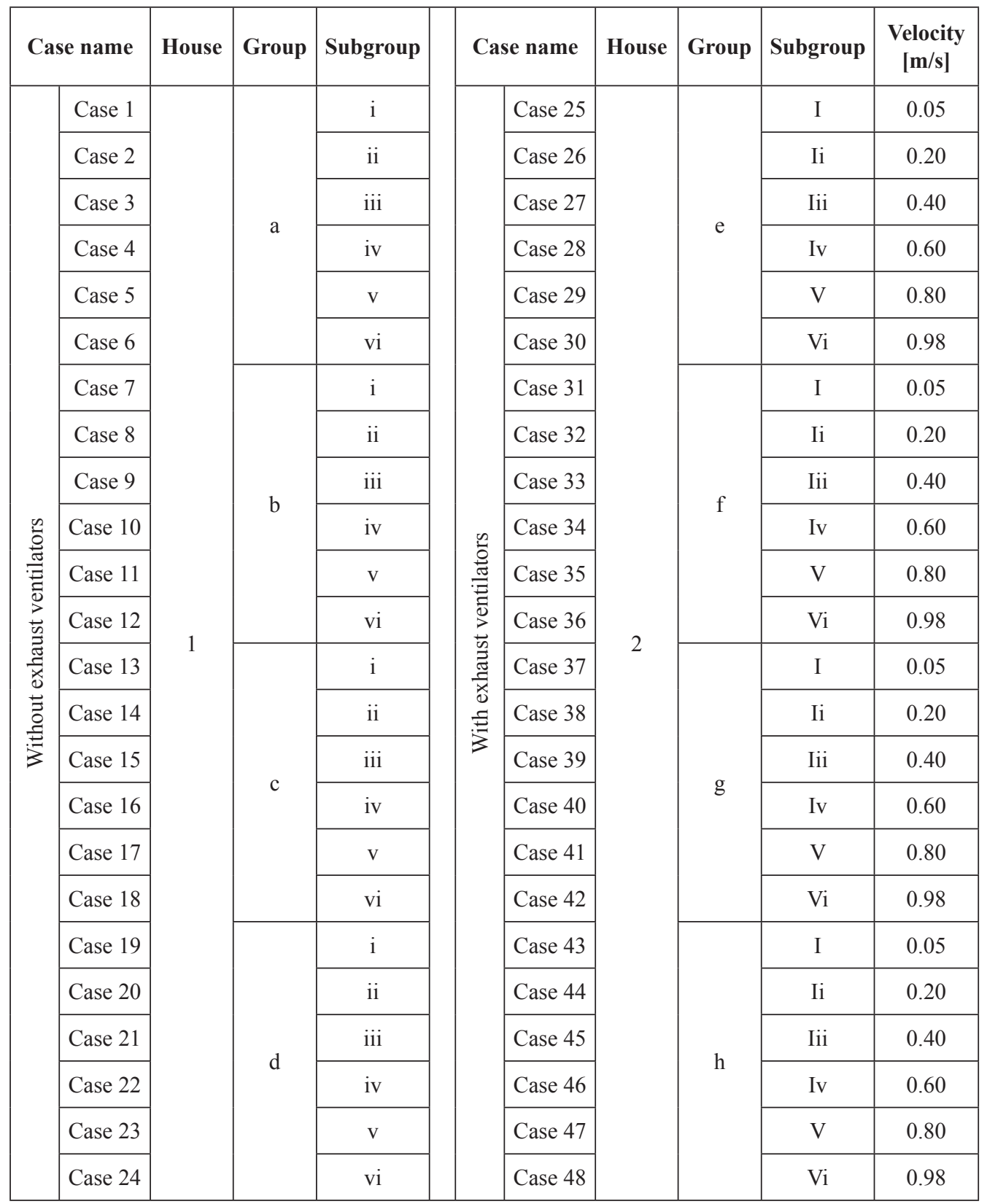




\subsection{Air QUALITY IN PERSONAL AND INDOOR BREATHING ZONE}

The average $\mathrm{CO}_{2}$ concentration in the breathing zone is the main index which assesses the indoor air quality. However, the resident body disturbs the mixture flow pattern in the indoor zone and changes this index. Thus, our analysis focused on the air quality in PBZ located at the front of the resident head. For the natural ventilation without exhaust ventilators, the air quality in PBZ was related strongly to the resident location and less to the inlet air velocity (Figure 7).

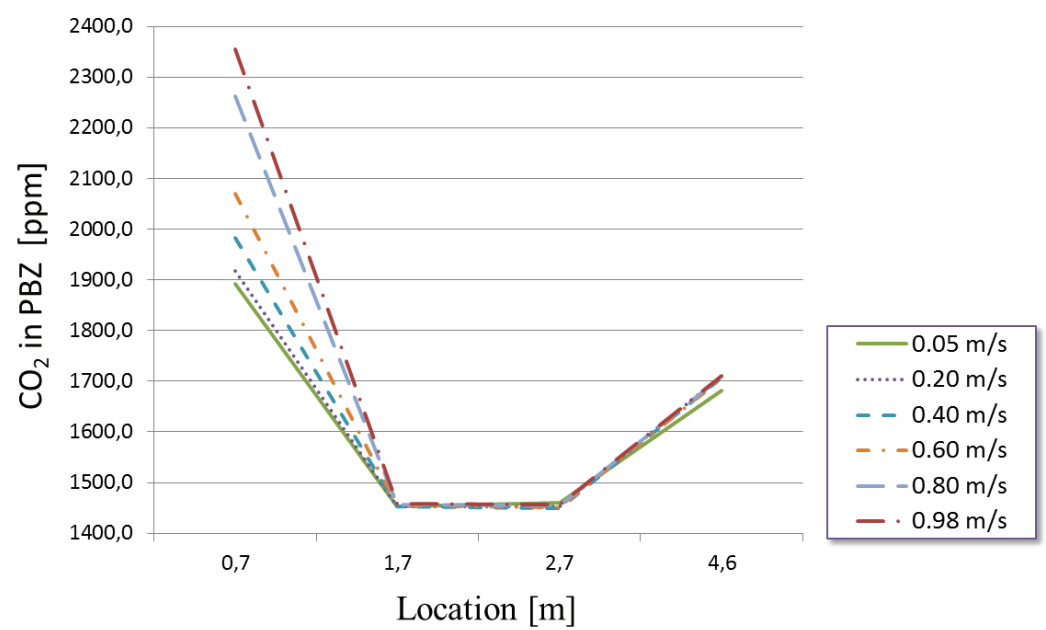

a)

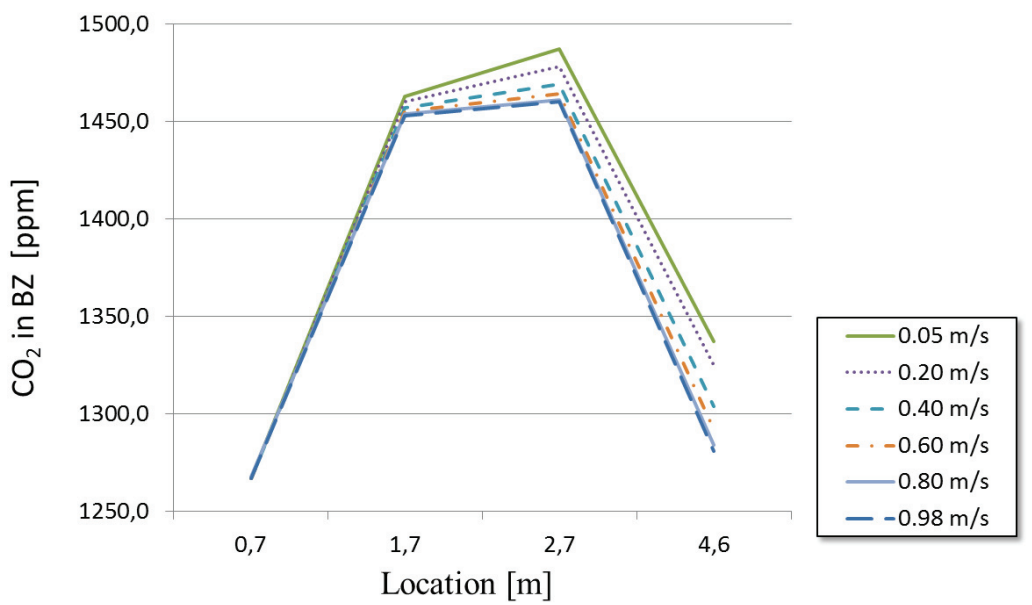

b)

Fig. 7. $\mathrm{CO}_{2}$ concentration depending upon resident location from external wall for natural ventilation without exhaust ventilator and different air inlet velocities: a) in Personal Breathing Zone and b) in Breathing Zone 
The highest $\mathrm{CO}_{2}$ concentration in $\mathrm{PBZ}$ was obtained for the resident location $\mathrm{I}(0.7 \mathrm{~m}$ from the window $)$ and the highest inlet air velocity $(0.98 \mathrm{~m} / \mathrm{s})$. The $\mathrm{CO}_{2}$ concentration in PBZ reached $2355 \mathrm{ppm}$ and exceeded significantly the dissatisfaction limit of $1389 \mathrm{ppm}$, while the $\mathrm{CO}_{2}$ concentration in $\mathrm{BZ}$ was $1267 \mathrm{ppm}$. The lower the inlet air velocity, the lower was the $\mathrm{CO}_{2}$ concentration in $\mathrm{PBZ}$. The $\mathrm{CO}_{2}$ concentration in $\mathrm{BZ}$ for the resident location I ( $0.7 \mathrm{~m}$ from the window) was $1267 \mathrm{ppm}$ at the air velocity of $0.98 \mathrm{~m} / \mathrm{s}$ (prevailing conditions) and was very close to the measured average value in BZ [2]. Such large differences in the $\mathrm{CO}_{2}$ concentration were explained by studying the flow pattern at the extreme inlet air velocities $(0.05 \mathrm{~m} / \mathrm{s}$ and $0.98 \mathrm{~m} / \mathrm{s})$.

The flow patterns were presented in the form of stream functions $\Psi(\mathrm{kg} / \mathrm{m} \mathrm{s})$ and particles traces. The stream function $\Psi$ was defined by its derivatives:

$$
\begin{aligned}
& \frac{\partial \Psi}{\partial x}=-\rho v_{y} \\
& \frac{\partial \Psi}{\partial y}=-\rho v_{x}
\end{aligned}
$$

where $x$ and $y$ are global Cartesian coordinates, and $v_{x}$ and $v_{y}$ are global Cartesian velocity components. The particles flow was traced in some control points located at the indoor edge of the inlet gap and at the top edge of PBZ (Figure 8). For the air inlet velocity of $0.98 \mathrm{~m} / \mathrm{s}$ (prevailing conditions), the upward flow was dominated by the

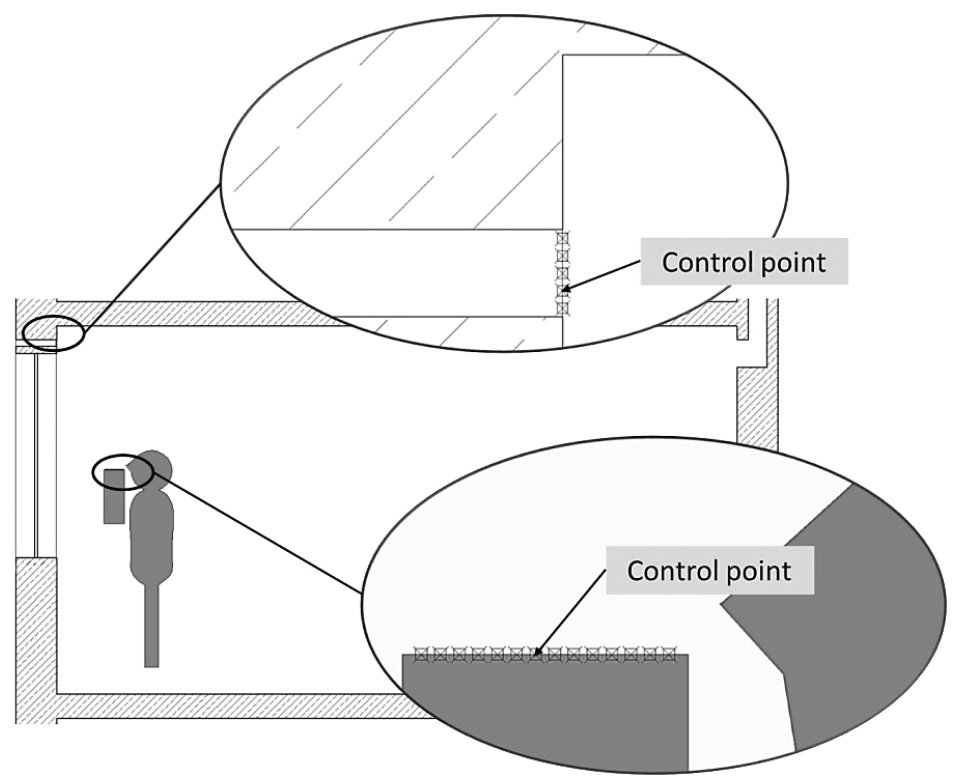

Fig. 8. Control points of particles flow in indoor zone 
forced convection from the imposed inlet velocity (Figure 9). After the fluid flowed out of the inlet gap, the main fluid flow slowed down significantly and turned towards the resident head with the velocity of $0.17 \mathrm{~m} / \mathrm{s}$ (Figure 10). Before it reached the head, the main flow partly bent again to form a small closed cell. This cell was located over the resident head near the window and was bounded by the ceiling and window. The main flow dropped further down, moved slightly towards the window, and slowed down to

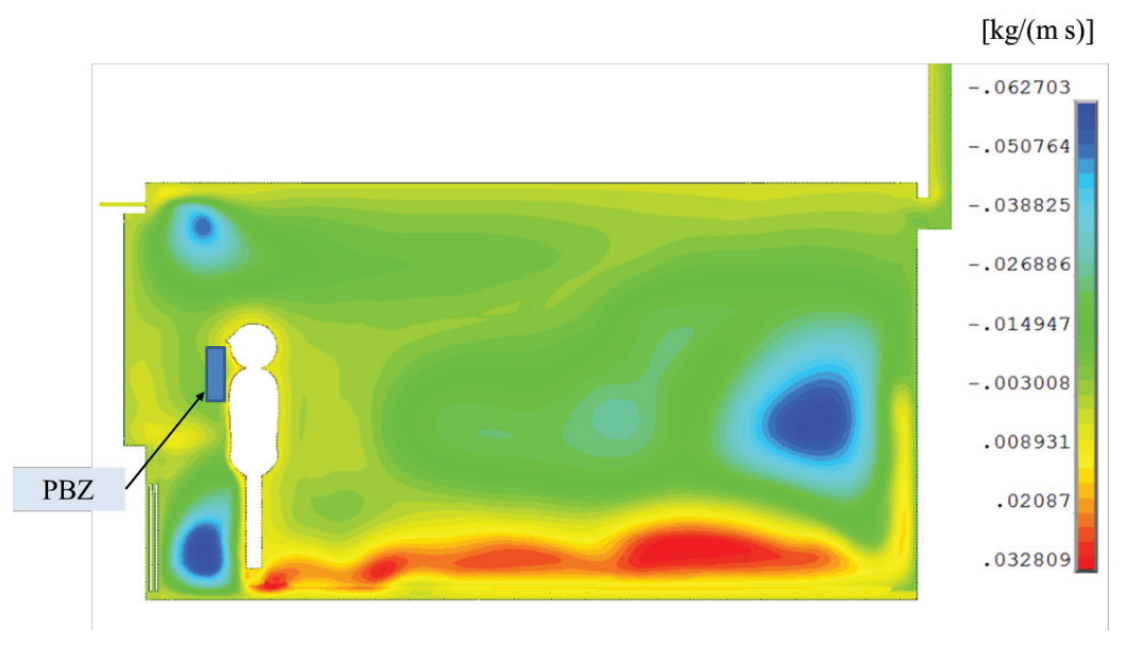

a)

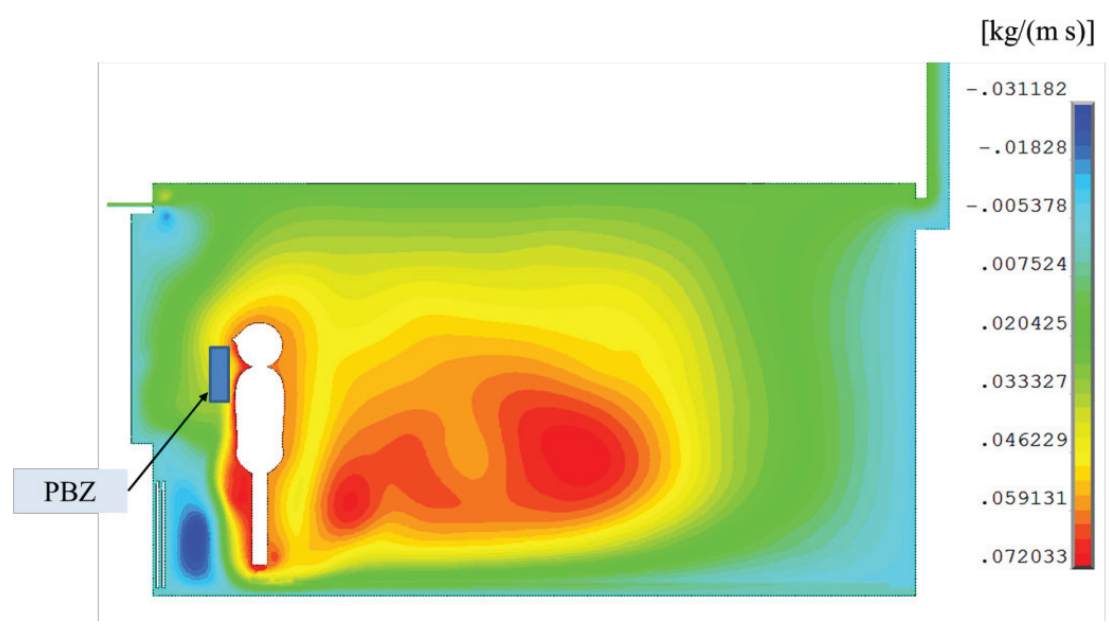

b)

Fig. 9. Stream function $\Psi[\mathrm{kg} / \mathrm{ms}]$ in indoor zone for resident located $0.7 \mathrm{~m}$ from window and natural ventilation without exhaust ventilator: a) inlet air velocity of $0.05 \mathrm{~m} / \mathrm{s}$ and b) inlet air velocity of $0.98 \mathrm{~m} / \mathrm{s}$ 
$0.07 \mathrm{~m} / \mathrm{s}$. The bending effect was caused by the natural convection developed around the radiator. However, the convection could not overcome inertial forces of the fresh air main flow. As result, a small convection flow cell was created near the radiator and the main flow dropped further down to the floor. Next, the main flow moved into BZ. It partly supplied the fresh air into BZ and partly flowed into the exhaust duct. This flow pattern separated PBZ from the fresh air flow, while BZ was supplied with the fresh air.

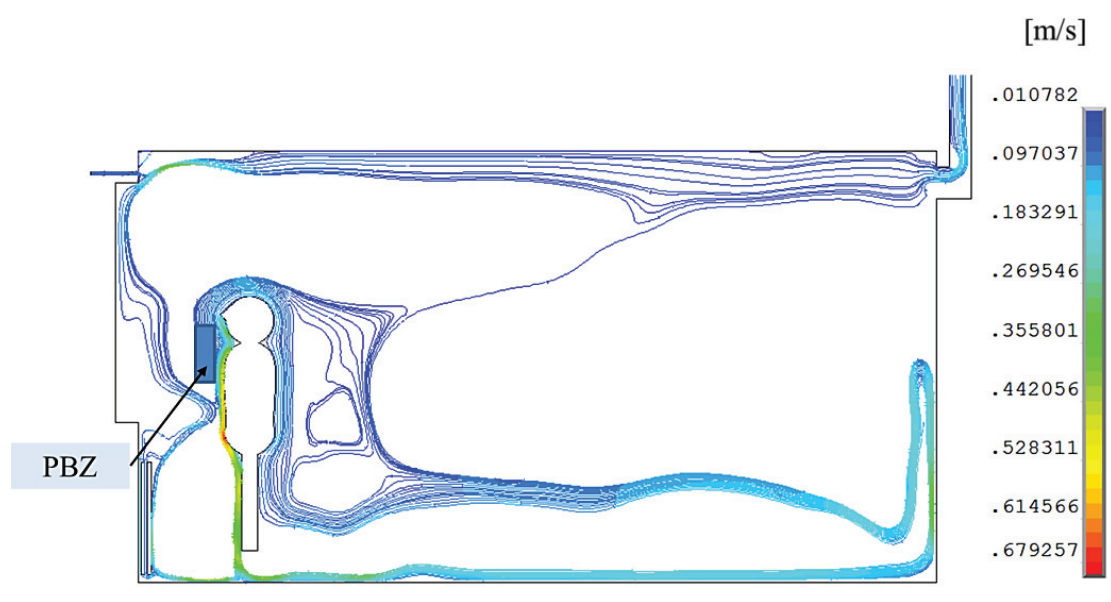

a)

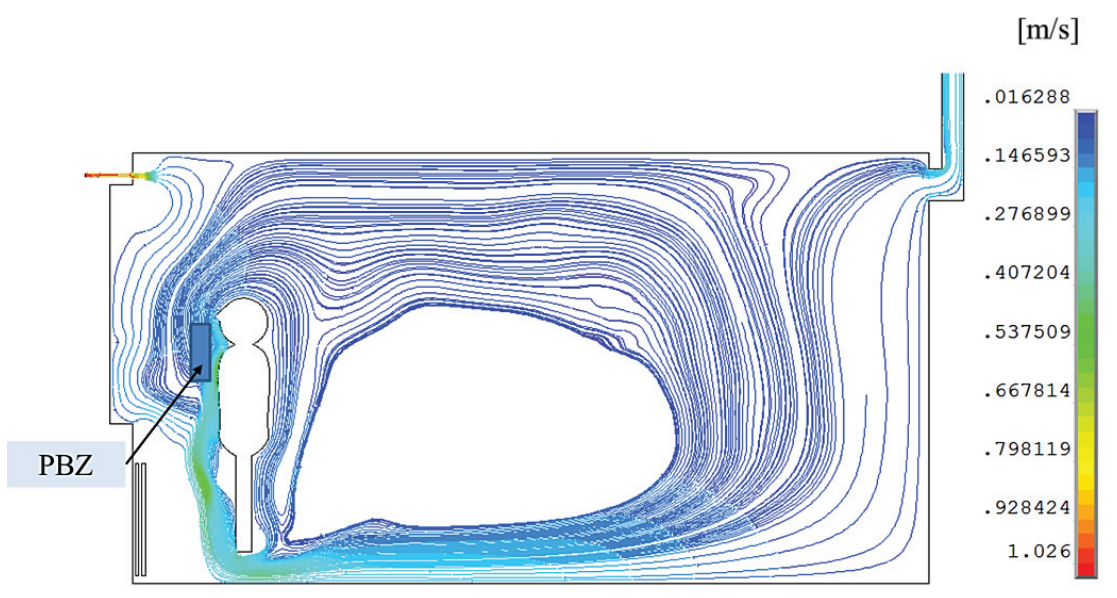

b)

Fig. 10. Particles flow trace in indoor zone for the resident located $0.7 \mathrm{~m}$ from the window and natural ventilation without exhaust ventilator: a) inlet air velocity of $0.05 \mathrm{~m} / \mathrm{s}$ and b) inlet air velocity of $0.98 \mathrm{~m} / \mathrm{s}$ 
It resulted in a significant increase of the $\mathrm{CO}_{2}$ concentration $(2355 \mathrm{ppm})$ in PBZ. The air- $\mathrm{CO}_{2}$ mixture flow pattern was significantly different at the inlet velocity of $0.05 \mathrm{~m} / \mathrm{s}$ (calm weather). Just after fluid flowed out of the inlet gap, the main flow moved up to the ceiling by convection developed by the radiator and went directly to the exhaust duct. The main flow, moving along the ceiling with the velocity of $0.04 \mathrm{~m} / \mathrm{s}$, supplied some fresh air to BZ. However, the dominating convective flow in the indoor zone was induced by the radiator and resident body. The dominating flow circulated in a large cell bounded by the back wall, floor, ceiling and resident body. This flow pattern resulted in extracting the good quality air from BZ and supplying it into PBZ. Thus, the $\mathrm{CO}_{2}$ concentration in PBZ was relatively low (1893 ppm) but higher than the limit of $1389 \mathrm{ppm}$, while the $\mathrm{CO}_{2}$ concentration in $\mathrm{BZ}$ still remained at $1267 \mathrm{ppm}$ and was lower than the limit value. For the resident in $\mathrm{BZ}$ (location II and III), the $\mathrm{CO}_{2}$ concentration in PBZ was being equalized to the $\mathrm{CO}_{2}$ concentration in $\mathrm{BZ}$ (about $1460 \mathrm{ppm}$ ) and was lower than the limit value. For these locations, the $\mathrm{CO}_{2}$ concentrations in $\mathrm{PBZ}$ and $\mathrm{BZ}$ did not depend on the inlet air velocity. In the case of the resident located near the back wall (location IV), the $\mathrm{CO}_{2}$ concentration in PBZ increased slightly over the limit up to 1700 ppm, however was still close to it. For this resident location, the $\mathrm{CO}_{2}$ concentration in $\mathrm{BZ}$ decreased to $1300 \mathrm{ppm}$. The $\mathrm{CO}_{2}$ concentrations in $\mathrm{PBZ}$ and $\mathrm{BZ}$ depended very slightly on the inlet air velocity.

Opposite to the no-ventilator case, with the natural ventilation with the exhaust ventilator, the air quality in PBZ was not only related to the resident location, but also to the inlet velocity (Figure 11). In turn, the $\mathrm{CO}_{2}$ concentration in $\mathrm{BZ}$ was affected by the resident location only. It was not surprising that the highest $\mathrm{CO}_{2}$ concentration in $\mathrm{BZ}$ (998 ppm ) was at the location III (just in BZ) and the inlet air velocity of $0.05 \mathrm{~m} / \mathrm{s}$. The $\mathrm{CO}_{2}$ concentration in PBZ was strongly related to the inlet air velocity for the resident location II (still in BZ) but relatively close to the window. The $\mathrm{CO}_{2}$ concentration varied from $1975 \mathrm{ppm}$ up to 2540 for the inlet air velocity $0.05-0.98 \mathrm{~m} / \mathrm{s}$. The differences in the $\mathrm{CO}_{2}$ concentration in PBZ could be explained by studying the flow pattern for at the extreme inlet air velocities. When the air inlet velocity was $0.98 \mathrm{~m} / \mathrm{s}$ (prevailing conditions), the upward flow was dominated by the forced convection from the imposed inlet velocity (Figure 12b). After the fluid flowed out of the inlet gap, the main flow slowed down to the velocity of $0.35 \mathrm{~m} / \mathrm{s}$. The inertial forces kept the main flow near the ceiling at the distance of $1.5 \mathrm{~m}$ from the inlet gap. Next, the main flow turned down to the resident head with the velocity of about $0.22 \mathrm{~m} / \mathrm{s}$ (Figure 13). Before it reached the resident head, the main flow bent again and formed a closed cell. The fresh air cell was located near the ceiling and almost $1 \mathrm{~m}$ above the resident head (away from PBZ). Instead of forming the fresh air cell, a small part of the main flow still moved towards the resident head and PBZ. However, before it reached PBZ, the fresh air flow bent downwards and passed PBZ. The fresh air flow was separated from PBZ by the natural convection developed around the human body (Figure 13). The fresh air flow bent again near the floor towards the back wall and split into two streams: one stream flowed along the floor and back wall up to the exhaust ventilator and second one moved up just 
behind the resident back and supplied BZ with the fresh air. The flow pattern resulted in low-intensity supplying of the fresh air to BZ, while PBZ remained almost without the fresh air. Hence, the average $\mathrm{CO}_{2}$ concentration in $\mathrm{BZ}$ lied below the limit value (1389 $\mathrm{ppm}$ ) and was equal to $978 \mathrm{ppm}$, but surprisingly the average $\mathrm{CO}_{2}$ concentration in PBZ increased significantly over the limit value (2540 ppm).

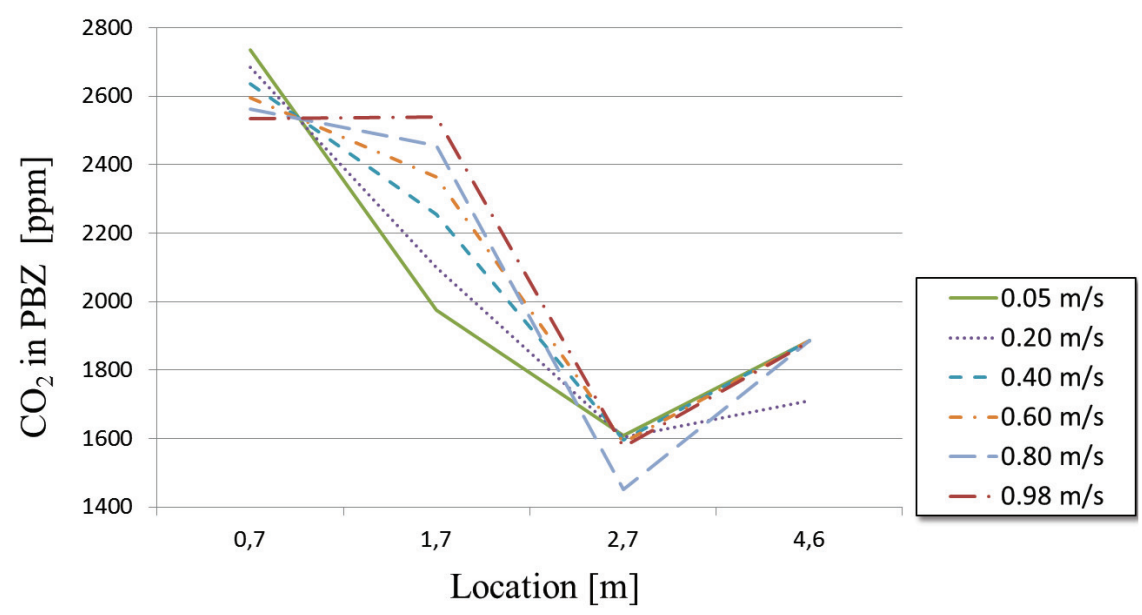

a)

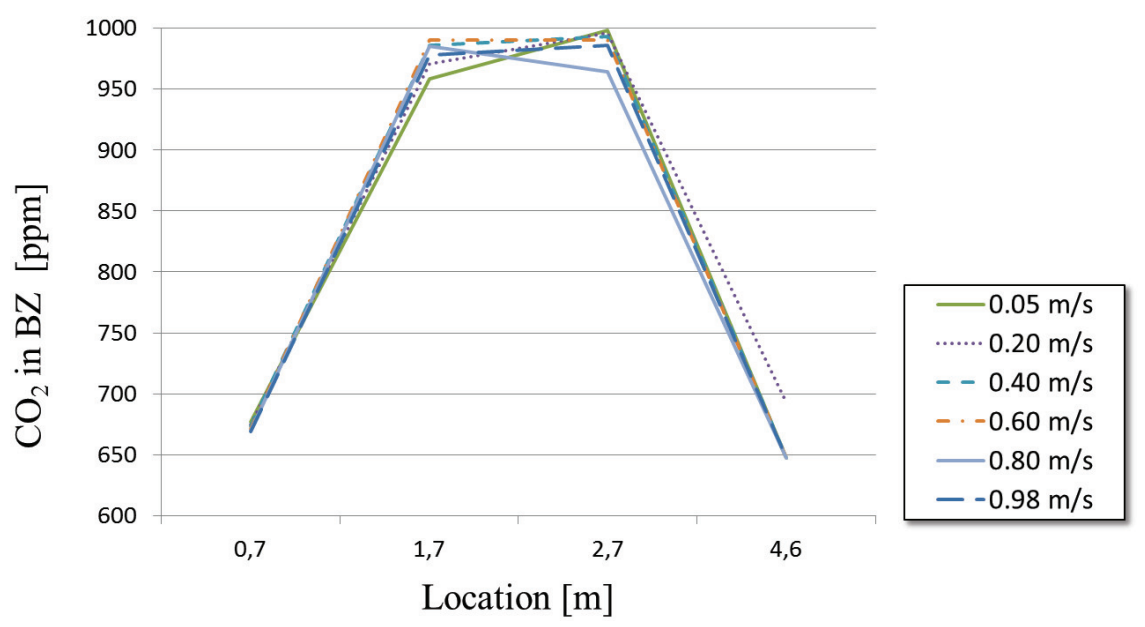

b)

Fig. 11. $\mathrm{CO}_{2}$ concentration depending upon resident location from external wall for natural ventilation with exhaust ventilator and different air inlet velocities: a) in Personal Breathing Zone and b) in Breathing Zone 
In contrast to the high inlet velocity $(0.98 \mathrm{~m} / \mathrm{s})$, the flow pattern of the air inlet velocity of $0.05 \mathrm{~m} / \mathrm{s}$ (calm weather) was significantly different. After the fluid flew out from the inlet gap, the main flow dropped down and bent to the window because the inertial forces could not keep the flow near the ceiling (Figure 12a). Close to the window bottom, the fresh air flow met a stream of the natural convection which was developed around the radiator. It pushed up the fresh air flow with the velocity of $0.15 \mathrm{~m} / \mathrm{s}$. The

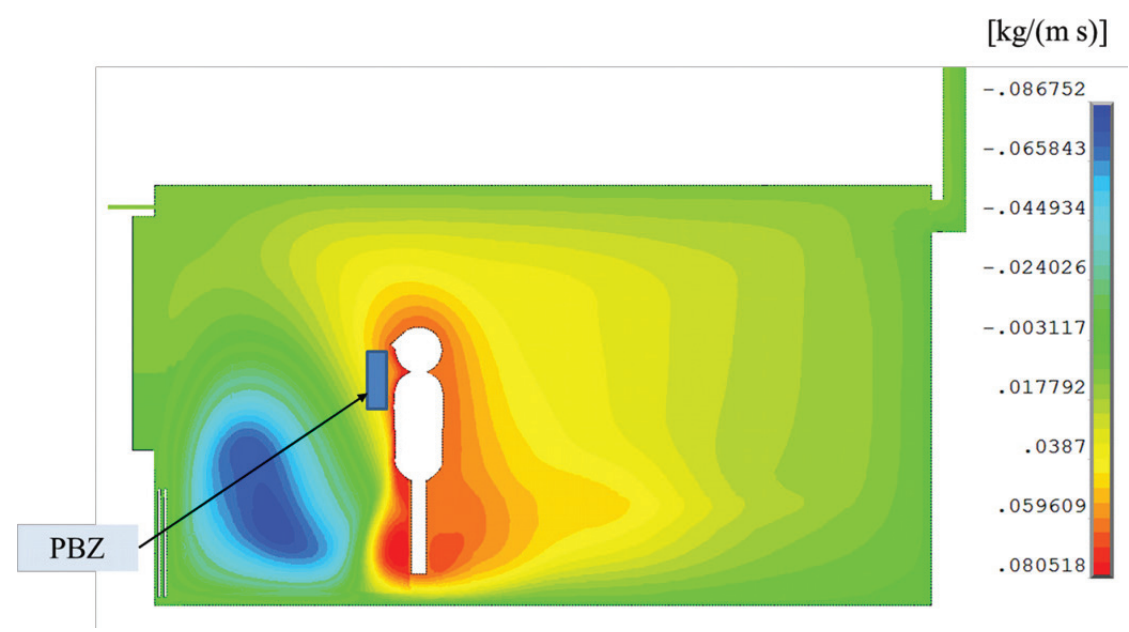

a)

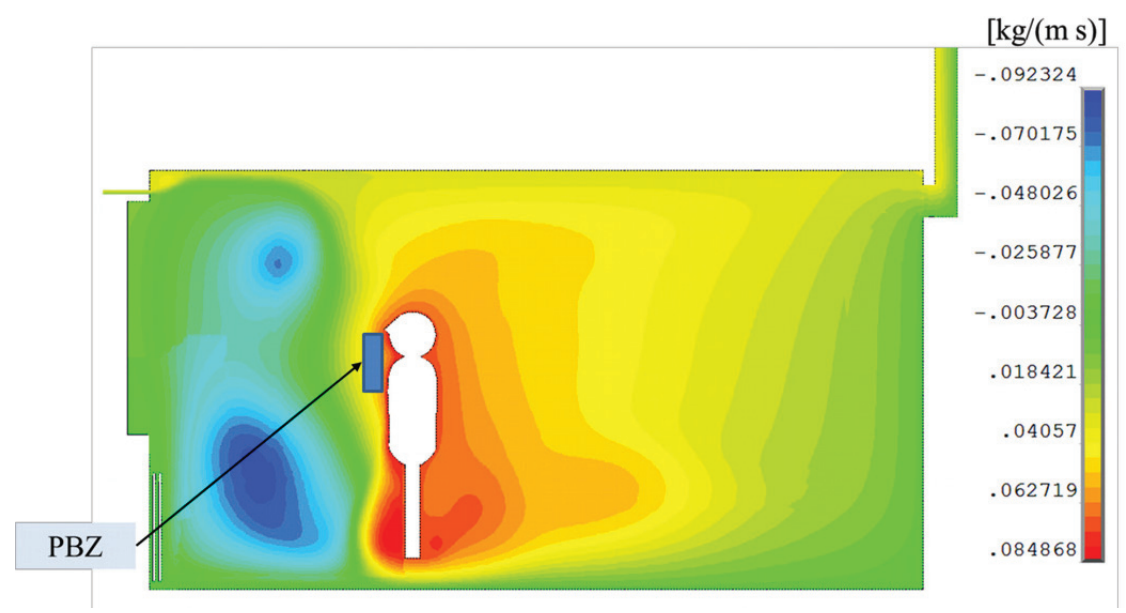

b)

Fig. 12. Stream function $\Psi[\mathrm{kg} / \mathrm{ms}]$ in indoor zone for resident located $1.7 \mathrm{~m}$ from window (location II) and for natural ventilation with exhaust ventilator: a) inlet air velocity of $0.05 \mathrm{~m} / \mathrm{s}$ and b) inlet air velocity of $0.98 \mathrm{~m} / \mathrm{s}$ 
effect of the natural convection was quickly diminished ( $0.8 \mathrm{~m}$ from the window) and the fresh air flow moved towards the floor. The fresh air flow passed PBZ and moved down to the floor. Due to the intensive natural convection developed around the human body $(0.45 \mathrm{~m} / \mathrm{s})$, a part of the fresh air flow bent up just behind the human back and flew around his body directly to PBZ. In this way, the fresh air was supplied to PBZ by decreasing the $\mathrm{CO}_{2}$ concentration to $1975 \mathrm{ppm}$. It was still above the limit value but

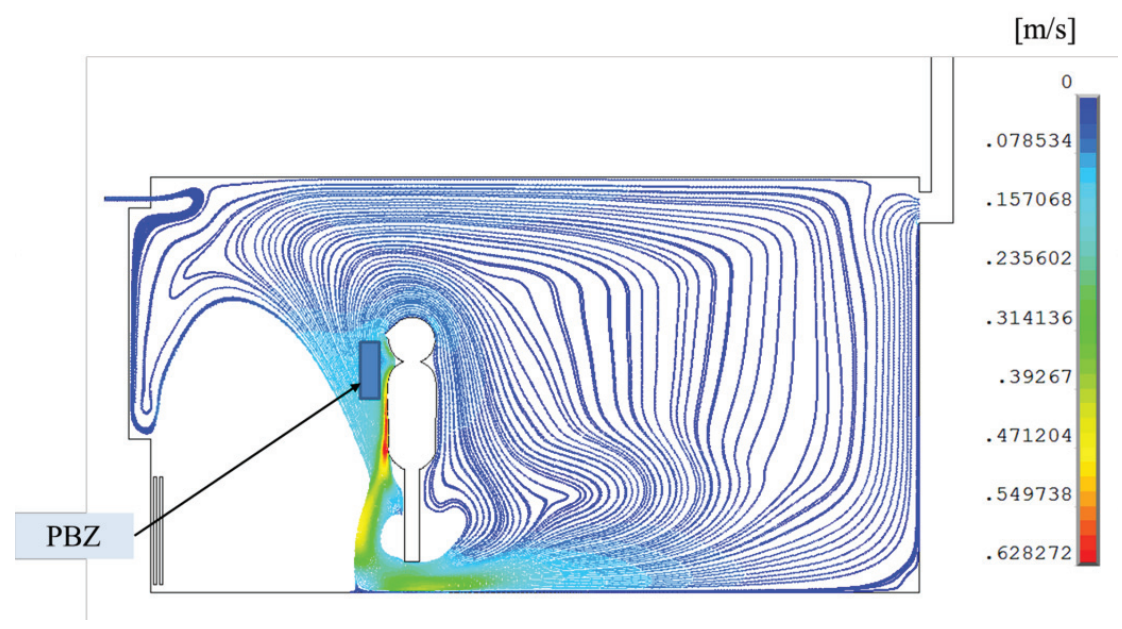

a)

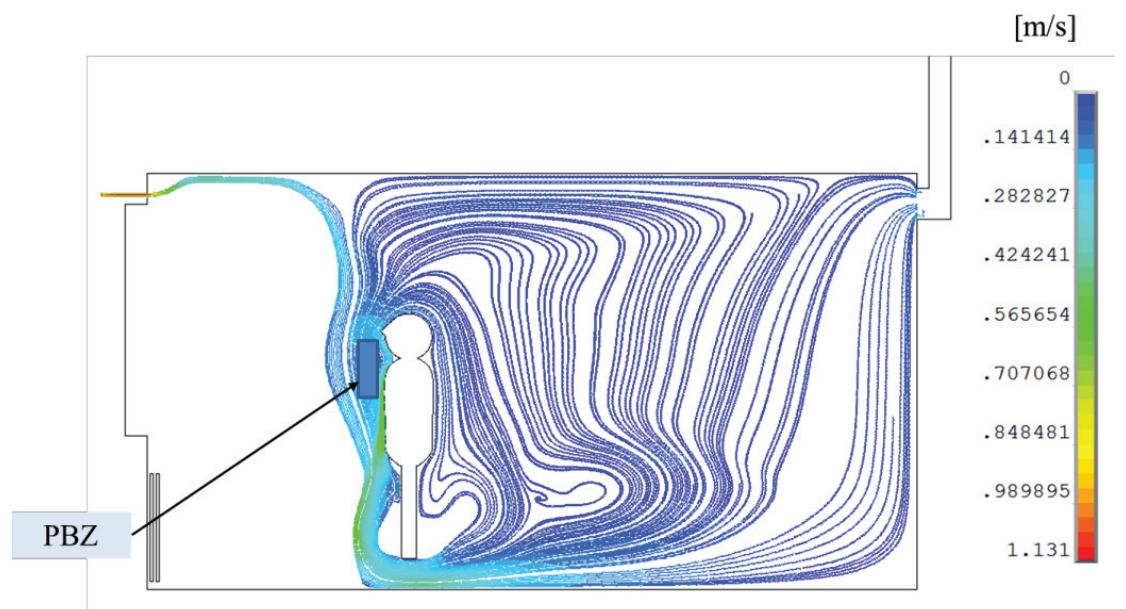

b)

Fig. 13. Particles flow trace in indoor zone for the resident located $1.7 \mathrm{~m}$ from the window (location II) and natural ventilation with exhaust ventilator: a) inlet air velocity of $0.05 \mathrm{~m} / \mathrm{s}$ and b) inlet air velocity of $0.98 \mathrm{~m} / \mathrm{s}$ 
significantly less than $2540 \mathrm{ppm}$ as for the fresh air inlet velocity of $0.98 \mathrm{~m} / \mathrm{s}$. This flow pattern very slightly affected the $\mathrm{CO}_{2}$ concentration in $\mathrm{BZ}(978 \mathrm{ppm})$ which was below the limit value of $1389 \mathrm{ppm}$.

The simulations results showed that the $\mathrm{CO}_{2}$ concentration in the Breathing Zone was related to the exhaust system. For the ventilation system without the exhaust ventilator, the $\mathrm{CO}_{2}$ concentration in $\mathrm{BZ}$ was only $7 \%$ above the limit (1389 ppm), while in

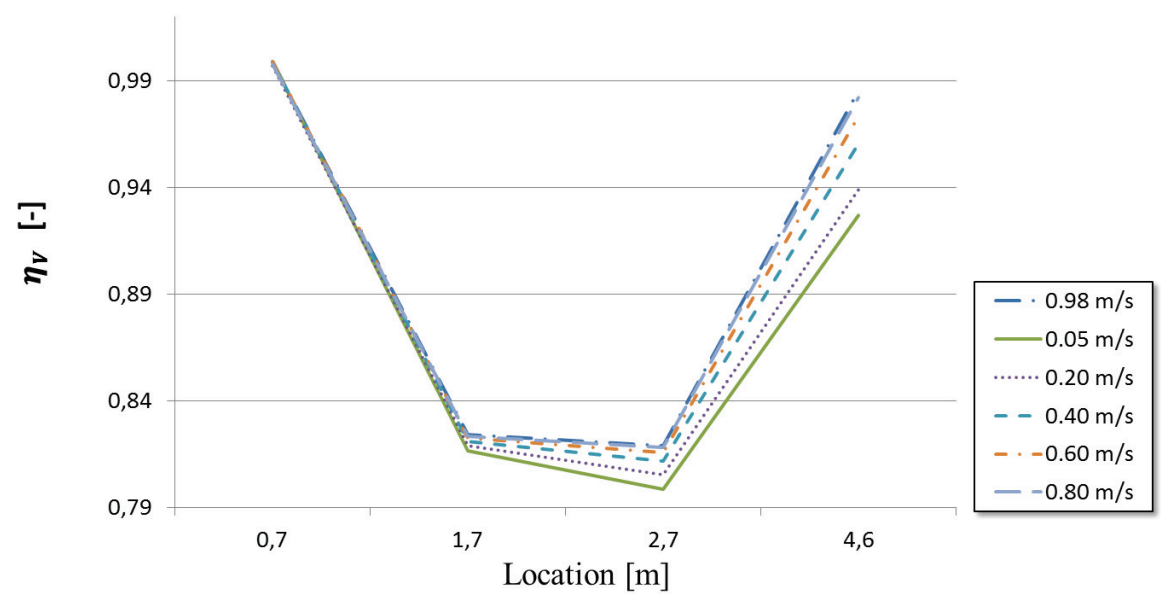

a)

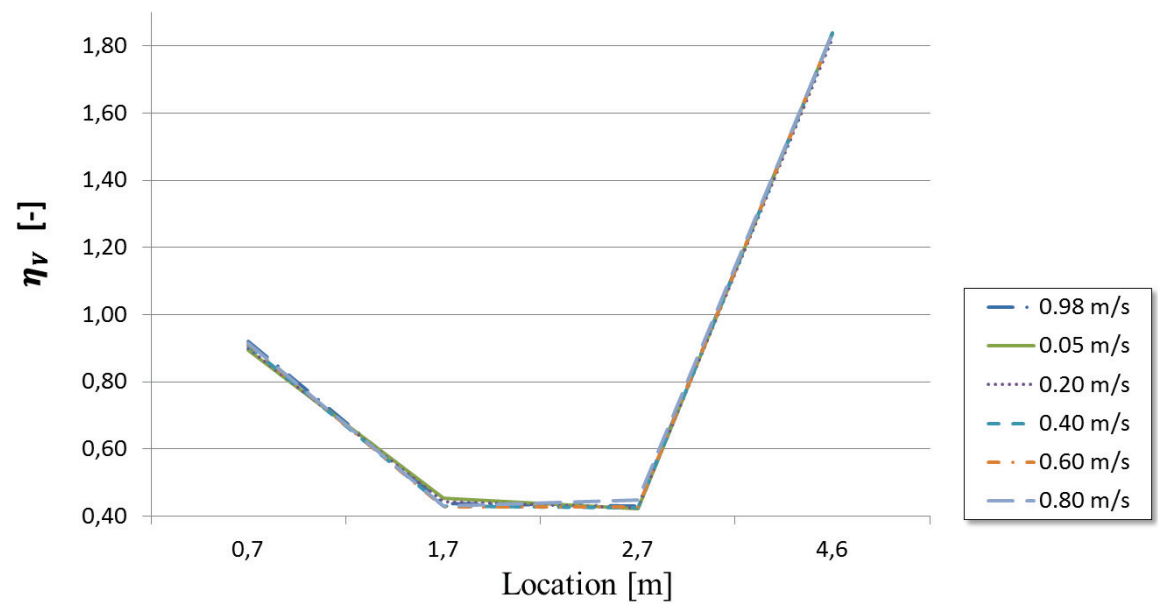

b)

Fig. 14. Ventilation effectiveness $\eta_{V}$ as function of resident location in indoor zone for different air inlet velocities: a) ventilation system without exhaust ventilators and b) ventilation system with exhaust ventilators 
the exhaust ventilator presence, the $\mathrm{CO}_{2}$ concentration in $\mathrm{BZ}$ was $39 \%$ below the limit. This result was confirmed by the measurements results [8]. The air quality obtained in questionnaires the notes "good" and "very good" for all ventilation systems. The $\mathrm{CO}_{2}$ concentration in BZ was strongly related to the resident location and could differ by $49 \%$. The highest $\mathrm{CO}_{2}$ concentration in BZ was for the location II and III (just inside BZ) using both ventilation systems. The fresh air inlet velocity influenced slightly the $\mathrm{CO}_{2}$ concentration in $\mathrm{BZ}$ (no more than $2 \%$ ). However, the flow pattern strongly affected the $\mathrm{CO}_{2}$ concentration in PBZ that strongly depended upon the resident location and fresh air inlet velocity but very slightly upon the ventilation system (with or without exhaust ventilators). The lowest $\mathrm{CO}_{2}$ concentration of $1450 \mathrm{ppm}$ in $\mathrm{PBZ}$ was computed at the resident location III ( $2.7 \mathrm{~m}$ from the window) and was very close to the limit value of $1389 \mathrm{ppm}$. Approaching the window, the $\mathrm{CO}_{2}$ concentration in PBZ rapidly increased. At the resident location I ( $0.7 \mathrm{~m}$ from the window), the $\mathrm{CO}_{2}$ concentration in PBZ reached $2734 \mathrm{ppm}$ and $2355 \mathrm{ppm}$ for the ventilation system with and without exhaust ventilators, respectively. It was surprising that the maximum $\mathrm{CO}_{2}$ concentration in PBZ with exhaust ventilators was higher than in the case of their absence. In accordance to the resident variable location, the ventilation effectiveness $\eta_{V}$ varied slightly in the range of $(0.80,1.00)$ for the ventilation system without exhaust ventilators (Figure 14a), while for the ventilation system with exhaust ventilators (Figure 14b), it strongly changed in the range of $(0.42,1.84)$. The effectiveness of the natural ventilation without exhaust ventilator was smaller than with the exhaust ventilator. However, the effectiveness of the natural ventilation without the exhaust ventilator was significantly less sensitive to the resident location in the indoor zone. Even though the effectiveness of the natural ventilation without the exhaust ventilator was smaller than the one with the exhaust ventilator, the average $\mathrm{CO}_{2}$ concentration in $\mathrm{PBZ}$ without the exhaust ventilator was by $16 \%$ lower than with the exhaust ventilator.

\subsection{THERMAL COMFORT IN INDOOR ZONE}

PMV, PD and PPD are the main indices to predict the thermal comfort in indoor zones of buildings. The thermal comfort indices were calculated for particular averaged indoor climate conditions and depend on many factors. The investigations results of the natural ventilation without exhaust ventilators showed that PMV was slightly affected by the resident location at high inlet air velocities $0.60-0.98 \mathrm{~m} / \mathrm{s}$ (Figure 15), while at low inlet air velocities $0.05-0.4 \mathrm{~m} / \mathrm{s}$, was strongly affected. However, PMV varied in the small range $(1.29,1.58)$ and was above the comfort level $(0.0 \pm 0.5)$. The significant variations of the thermal comfort with respect to the air inlet velocity were obtained at the resident locations near the window only. The thermal comfort variations could be neglected for other locations. In the case of the exhaust ventilator, PMV was strongly dependent upon the resident location and slightly upon the air inlet velocity (Figure 15b). It was surprising that an almost linear relationship between the resident location and PMV was obtained while the effect of the air inlet velocity was small enough to be neglected. The 
predicted percentage of dissatisfied (PPD) depended solely on PMV. Hence, PPD variations were similar to PMV ones. When exhaust ventilators were absent, PPD varied between $39.80 \%$ and $55.11 \%$, and in the presence of exhaust ventilators, PPD similarly varied $39.75 \%-55.25 \%$. These results do not correspond to the resident opinions collected in questionnaires during the experimental campaign [2]. The thermal comfort perception obtained the notes "good" and "very good" for all ventilation systems. PMV

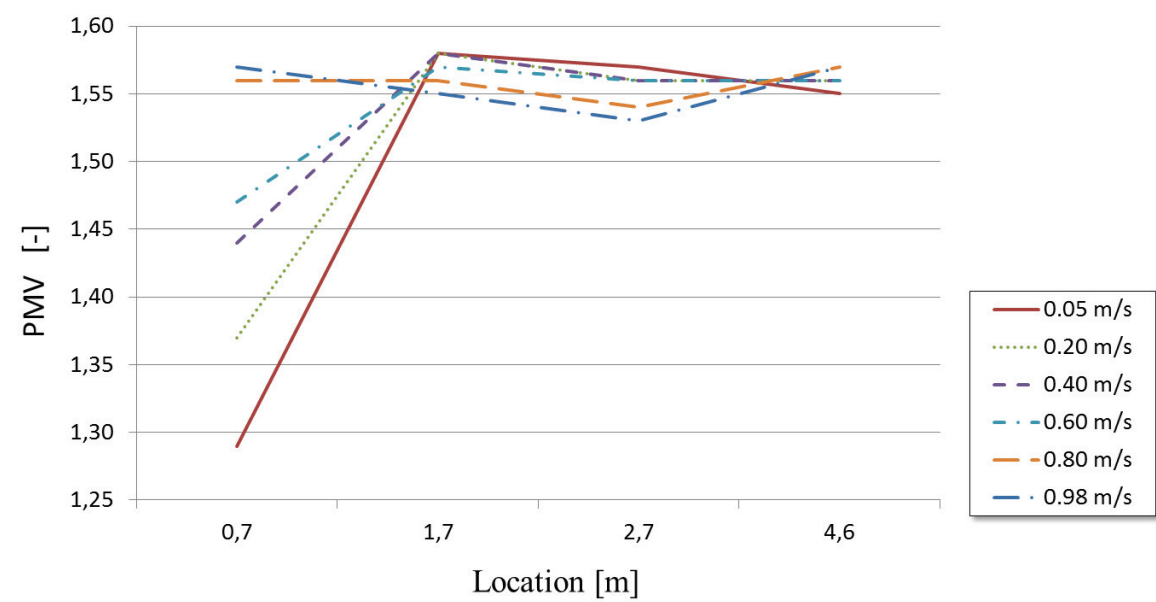

a)

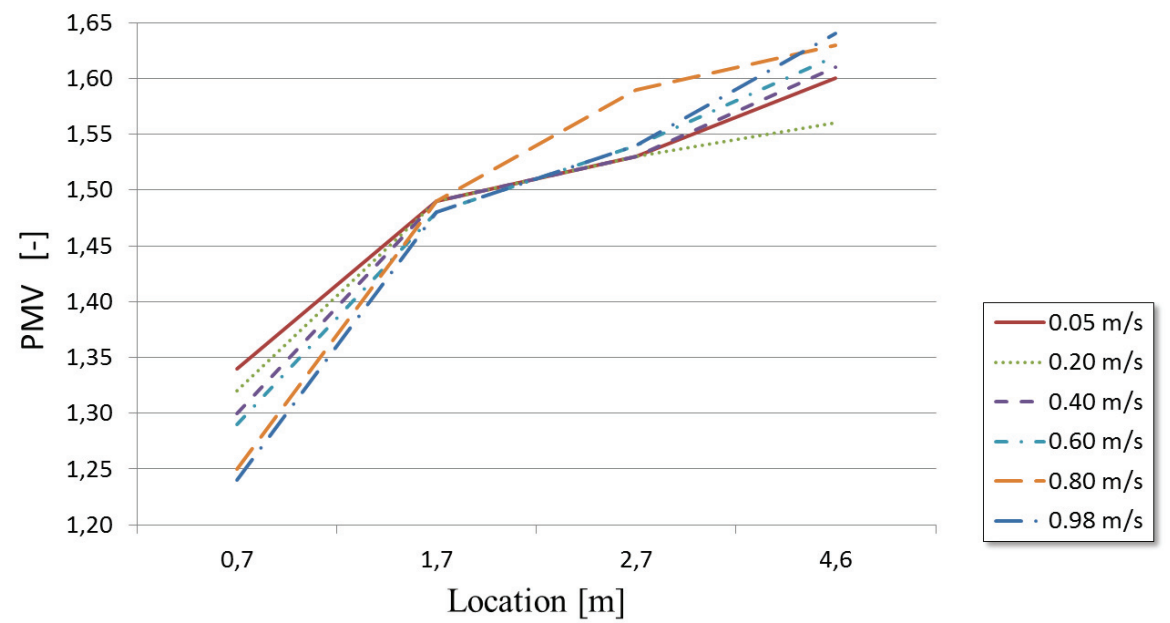

b)

Fig. 15. PMV index depending upon resident location in indoor zone for different air inlet velocities: a) ventilation system without exhaust ventilators and b) ventilation system with exhaust ventilators 
and PPD express the warm and cold discomfort of the body. But the thermal dissatisfaction can also be caused by unwanted cooling or heating of one particular body part. The local discomfort can be caused either by an abnormally high vertical temperature difference between the head and ankles or by too-warm/too-cool floor. It can be expressed in terms of percentage dissatisfied (PD). The PD index implicitly takes under consideration the resident location and air flow pattern. It can explain a discrepancy

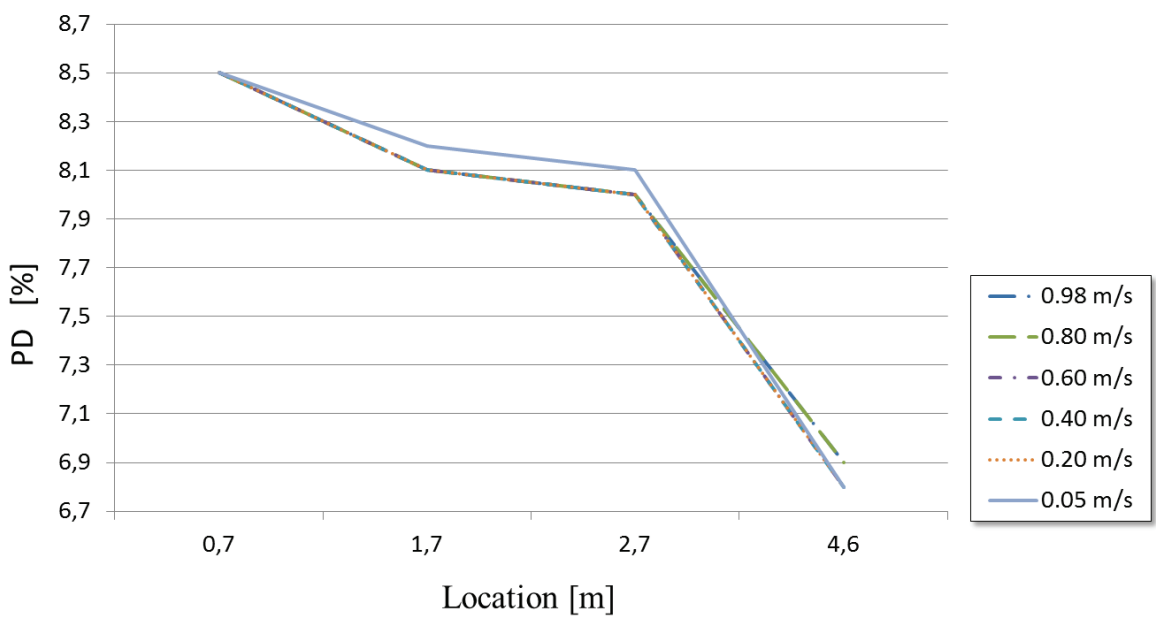

a)

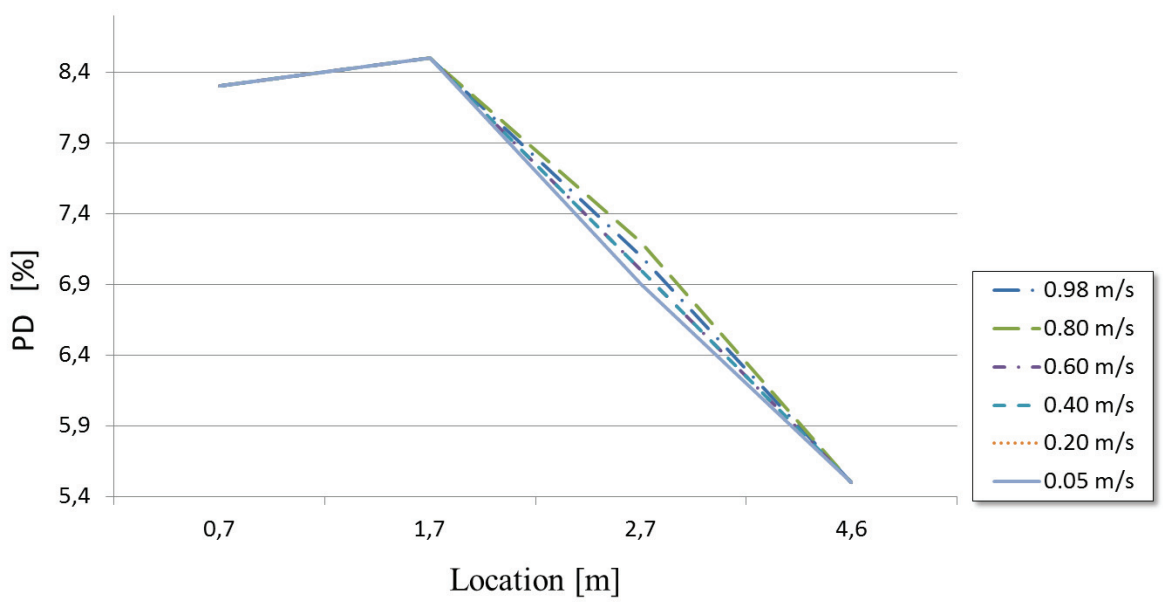

b)

Fig. 16. PD index depending upon resident location in indoor zone for different air inlet velocities: a) ventilation system without exhaust ventilators and b) ventilation system with exhaust ventilators 
between simulation results and experimental results. For the ventilation system without exhaust ventilators, PD was slightly dependent upon the resident location (Figure 15a) and varied in the range of $6.8 \%-8.5 \%$. The relationship between PD and the air inlet velocity was negligible. When the exhaust ventilator was present (Figure 15b), the PD variations were slightly higher $5.5 \%-8.5 \%$. However, in both cases, PD was small and

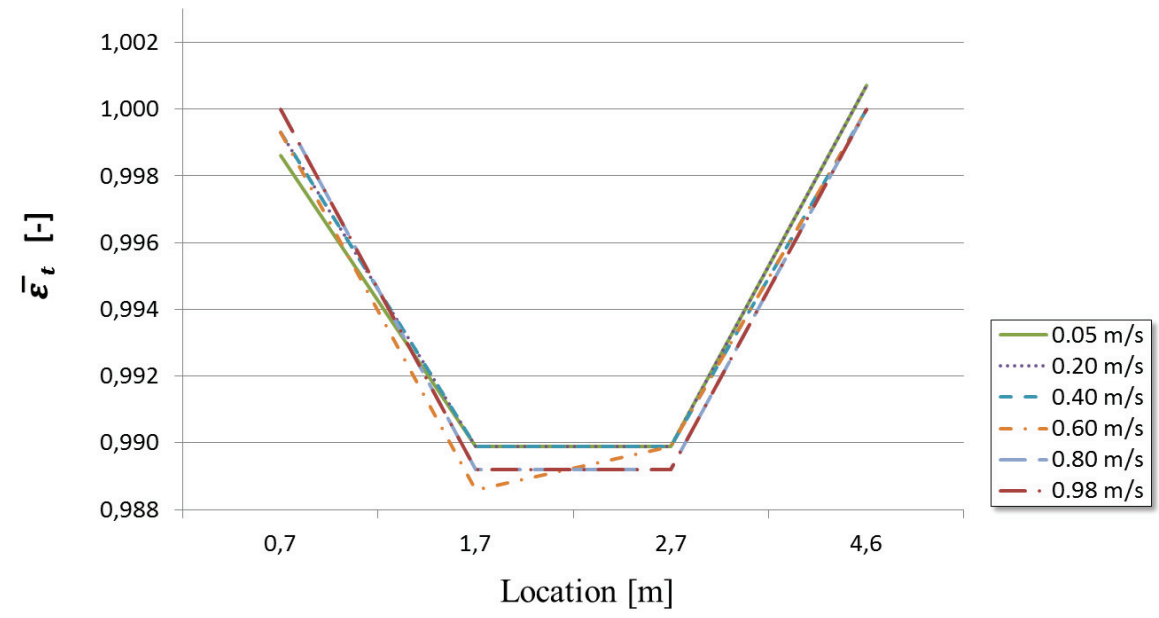

a)

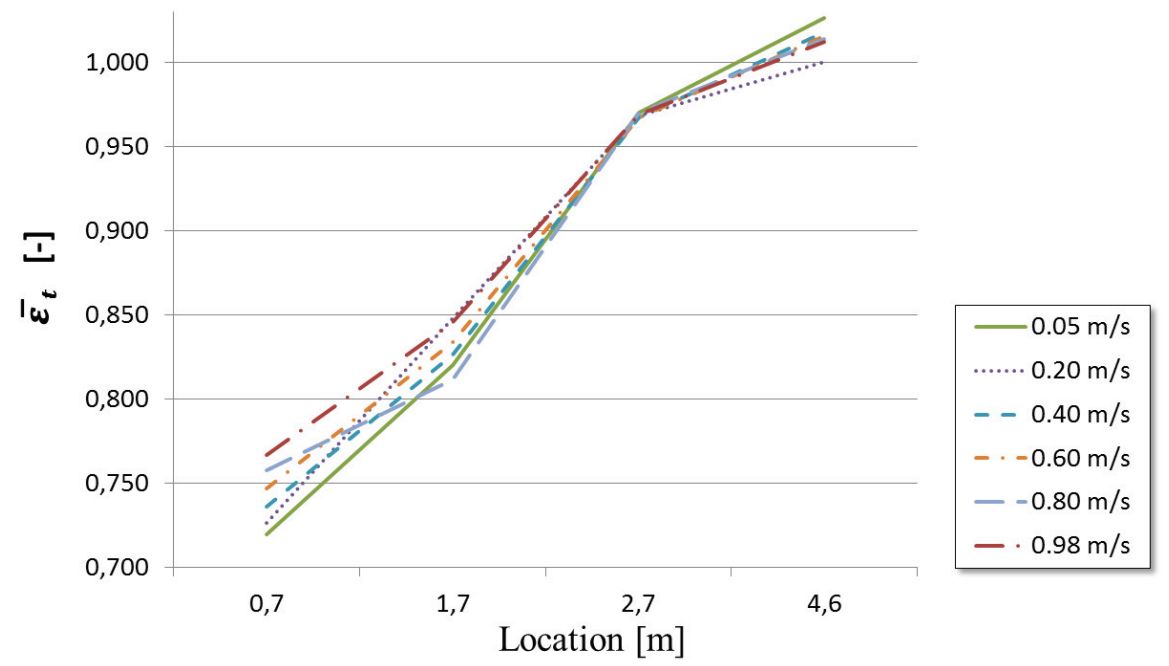

b)

Fig. 17. Overall ventilation effectiveness for temperature distribution $\bar{\varepsilon}_{t}$ depending upon resident location in indoor zone for different air inlet velocities: a) ventilation system without exhaust ventilators and b) ventilation system with exhaust ventilators 
was lower than the limit value of $10 \%$ [27]. The variations of the overall ventilation effectiveness for the temperature distribution $\bar{\varepsilon}_{t}$ were small enough to be neglected for the ventilation system without exhaust ventilators (Figure 17). The average value of $\bar{\varepsilon}_{t}$ was close to 1.0. This value indicates that the higher the value, the more homogeneous is the temperature distribution. Contrary to the ventilation system without exhaust ventilators, the ventilation effectiveness $\bar{\varepsilon}_{t}$ was strongly influenced by the resident location and slightly by the air inlet velocity for exhaust ventilators (Figure 17b). The effect of the air inlet velocity on the ventilation effectiveness was negligible. However, the resident location significantly influenced the effectiveness $\bar{\varepsilon}_{t}$. The ventilation effectiveness $\bar{\varepsilon}_{t}$ varied from 0.72 for the location I (near the window) up to 1.02 for the location IV (near the back-wall). The ventilation effectiveness decreased when the resident was closer to the window. The investigations results showed surprisingly that the average effectiveness of the natural ventilation with the exhaust ventilator was smaller than the one without it.

While the overall indices (PMV and PPD) exceeded slightly the thermal comfort range, the local index $\mathrm{PD}$ was still within the comfort range. Comparing the experimental results [2] and numerical results, it can be concluded that the overall indices overestimate the thermal comfort in the indoor zone, while the local indices give a more realistic prediction of the human behaviour.

\section{Conclusions}

The numerical results show that the $\mathrm{CO}_{2}$ concentration in the Breathing Zone depends on the resident location in the indoor zone. However, the $\mathrm{CO}_{2}$ concentration was maintained below the limit (1389 ppm) solely for the ventilation system with the exhaust ventilator, while in the case of the exhaust ventilator absence it was very close to the limit value $(7 \%)$. Thus, the variations of the $\mathrm{CO}_{2}$ concentration in $\mathrm{BZ}$ caused by changes of the resident location in the indoor zone are not able to explain the residents' dissatisfaction leading them to open operable windows that was observed during experiments [2].

In contrast to the overall air quality in $\mathrm{BZ}$, the local $\mathrm{CO}_{2}$ concentration in the Personal Breathing Zone PBZ strongly depends on the resident location, fresh air inlet velocity and ventilation system type. The highest $\mathrm{CO}_{2}$ concentration in $\mathrm{PBZ}$ was calculated for the natural ventilation system with the exhaust ventilator and for the resident located close to the window ( $0.7 \mathrm{~m}$ from the window). The $\mathrm{CO}_{2}$ concentration in PBZ reached $2734 \mathrm{ppm}$ exceeding significantly the satisfaction limit of $1389 \mathrm{ppm}$, while the $\mathrm{CO}_{2}$ concentration in $\mathrm{BZ}$ was still under this limit value. The significant increase of the $\mathrm{CO}_{2}$ concentration in PBZ may explain the temporary human dissatisfaction of the indoor air quality that leads to opening operable windows.

Although the effectiveness of the natural ventilation without the exhaust ventilator was smaller than with the exhaust ventilator, the average $\mathrm{CO}_{2}$ concentration in $\mathrm{PBZ}$ was by $16 \%$ smaller without exhaust ventilators. 
While the overall indices (PPM and PPD) exceeded slightly the thermal comfort range, the local index PD was within the comfort range. As compared to the experimental results [2], the overall indices overestimate slightly the thermal comfort in the indoor zone, while the local indices (e.g. PD) give a more realistic prediction of the human behaviour. However, the thermal comfort indices were very close to their limits. Thus, the thermal conditions in the indoor zone could not negatively affect the residents' behaviour.

Since the $\mathrm{CO}_{2}$ concentration is not the only factor influencing IAQ, the effect of local variations of other factors on the resident behaviour has to be also investigated (e.g. air humidity and VOCs). In addition, a more accurate 3D numerical model has to be applied (it is now under preparation).

\section{REFERENCES}

1. F. Meyer, Niedrigenergiehäuser Heidenheim: Hauskonzepte und erste Meßergebnisse, EggensteinLeopoldshafen: Fachinformationszentrum, Karlsruhe, Bine Projekt Info-Service 1993; Nr. 9.

2. T. Maier, M. Krzaczek, J. Tejchman. Comparison of physical performances of the ventilation systems in low-energy residential houses. Energy and Building 2009, 41, 337-353.

3. G. Y. Yun, K. SteEmers, Behavioural, physical and socio-economic factors in household cooling energy consumption. Applied Energy 2011, 88, 2191-2000.

4. A. Roetzel, A. Tsangrassoulis, U. Dietrich, S. Busching, A review of occupant control on natural ventilation. Renewable and Sustainable Energy Reviews 2010, 14, 1001-1013.

5. T. A. Lu, Knuutila, M. Viljanen, X. Lu. A novel methodology for estimating space air change rates and occupant $\mathrm{CO} 2$ generation rates from measurements in mechanically-ventilated buildings. Building and Environment 2010, 45, 1161-1172.

6. G. M. Stavrakakis, D. P. Karadimou, P. L. Zervas, H. Sarimveis, N. C. Markatos. Selection of window sizes for optimizing occupational comfort and hygiene based on computational fluid dynamics and neural networks. Building and Environment 2011, 46, 298-314.

7. ASHRAE. ASHRAE standard 62.1 - ventilation for acceptable indoor air quality. Atlanta, GA: American Society of Heating, Refrigerating and Air-Conditioning Engineers 2006.

8. P. O. FANGER. Human requirement in future air-conditioned environments: a search for excellence. In: Proceedings of ISHVAC'99, Shenzhen, China, 1999, 86-92.

9. G. M. Stavrakakis, P. L. Zervas, H. Sarimveis, N. C. Markatos. Development of a computational tool to quantify architectural design effects on thermal comfort in naturally ventilated rural houses. Building and Environment 2010, 45, 1, 65-80.

10. S, Murakami, S. Kato, J. Zeng. Development of a computational thermal manikin-CFD analysis of thermal environment around human body. In: Proceedings of Tsinghua-HVAC'95, Beijing, China 1995, 2, 349-54.

11. EN 13779. Ventilation for non-residential buildings - Performance requirements for ventilation and room-conditioning systems, 2007.

12. B. E. Launder, D. B. Spalding. The numerical computation of turbulent flows. Computer Methods in Applied Mechanics and Engineering 1974, 3,269-289.

13. G. Brager, G. Paliaga, R. De Dear. Operable Windows, personal control and occupant comfort. ASHRAE Transactions 2004, 110 (Part 2).

14. ISO 16814. Building environment design - Indoor air quality - Methods of expressing the quality of indoor air for human occupancy, 2008. 
15. S. M. B. Beck, S. C. Grinsted, S. G. Blakey. Worden, K. A novel design for panel radiators. Applied Thermal Engineering 2004, 24, 1291-1300.

16. S. B. M. Beck, S. G. Blakey, M. C. Chung. The effect of wall emissivity on radiator heat output. Building Services Engineering Research and Technology 2001, 22, 185-194.

17. S. Murakami, S. Kato, J. Zeng. Combined simulation of airflow, radiation and moisture transport for heat release from a human body, Building and Environment 2000, 35, 489-500.

18. J. Li, Li, Y. S. J. WAy, Zhan, Y. A. Ho, J. Li, E. Lam. Effect of green roof on ambient $\mathrm{CO}_{2}$ concentration. Building and Environment 2010, 45, 2644-2651.

19. T. M. Lawrence, J. E. Braun. A methodology for estimating occupant $\mathrm{CO}_{2}$ source generation rates from measurements in small commercial buildings. Building and Environment 2007, 42, 623-639.

20. S. Hyun, C. Kleinstreuer. Numerical simulation of mixed convection heat and mass transfer in a human inhalation test chamber. International Journal of Heat and Mass Transfer 2001, 44, 2247-60.

21. Y. YANES, C. J. YAPP. Indoor and outdoor urban atmospheric CO2: Stable carbon isotope constraints on mixing and mass balance, Applied Geochemistry 2010, 25, 1339-1349.

22. ANSYS Inc. ANSYS Release 11.0. Documentation, 2007.

23. S. Murakami, S. Kato, J. Zeng. Flow and temperature fields around human body with various room air distribution, CFD study on computational thermal manikin - Part I, ASHARE Transactions 1997, 103, 3-15.

24. M. Krzaczek, J. Tejchman. Indoor Air quality and thermal comfort in naturally ventilated low-energy residential houses. Air Quality Monitoring and Modeling (eds. Sunil Kumar and Rakesh Kumar), 79-116, 2012.

25. ISO 7730. Ergonomics of the thermal environment. Analytical determination and interpretation of thermal comfort using calculation of the PMV and PPD indices and local thermal comfort criteria. Annex D, 2005.

26. H. Awbi. Ventilation of building, E \& FN Spon, 2003.

27. M. J. Hodgson, J. Frohliger, E. Permar, C. Tidwell, N., D. Traven, S., A. Olenchock, M. Karpf. Symptoms and Microenvironmental Measures in Nonproblem Buildings, Journal of Occupational and Environmental Medicine, 1991, 33(4): 527-533

28. J. A. Duffie, W. A. Beckman. Solar Engineering of Thermal Processes, New York: John Wiley and Sons 1991.

29. HIGROSYSTEM. Technical data specification of ventilator V2A, www.higrosystem.com, 2012 (in polish). 